\title{
The interaction of disulfiram and $\mathrm{H}_{2} \mathrm{~S}$ metabolism in inhibition of aldehyde dehydrogenase activity and liver cancer cell growth
}

by

\begin{abstract}
Ethan $\underline{\text { Read }}$
A thesis submitted in partial fulfillment

of the requirements for the degree of

Master of Science (MSc) in Chemical Sciences
\end{abstract}

The Faculty of Graduate Studies

Laurentian University

Sudbury, Ontario, Canada

(C) Ethan Read, 2021 


\section{THESIS DEFENCE COMMITTEE/COMITÉ DE SOUTENANCE DE THÈSE Laurentian Université/Université Laurentienne Office of Graduate Studies/Bureau des études supérieures}

Title of Thesis

Titre de la thèse

Name of Candidate

Nom du candidat

Degree

Diplôme

Department/Program

Département/Programme
The interaction of disulfiram and $\mathrm{H}_{2} \mathrm{~S}$ metabolism in inhibition of aldehyde dehydrogenase activity and liver cancer cell growth

Read, Ethan

Master of Science

Chemical Sciences

Date of Defence

Date de la soutenance June 29, 2021

\section{APPROVED/APPROUVÉ}

Thesis Examiners/Examinateurs de thèse:

Dr. Guangdong Yang

(Supervisor/Directeur(trice) de thèse)

Dr. Eric Gauthier

(Committee member/Membre du comité)

Dr. Sabine Montaut

(Committee member/Membre du comité)

Dr. Wensheng Qin

(External Examiner/Examinateur externe)

Approved for the Office of Graduate Studies Approuvé pour le Bureau des études supérieures Tammy Eger, PhD

Vice-President Research (Office of Graduate Studies)

Vice-rectrice à la recherche (Bureau des études supérieures)

Laurentian University / Université Laurentienne

\section{ACCESSIBILITY CLAUSE AND PERMISSION TO USE}

I, Ethan Read, hereby grant to Laurentian University and/or its agents the non-exclusive license to archive and make accessible my thesis, dissertation, or project report in whole or in part in all forms of media, now or for the duration of my copyright ownership. I retain all other ownership rights to the copyright of the thesis, dissertation or project report. I also reserve the right to use in future works (such as articles or books) all or part of this thesis, dissertation, or project report. I further agree that permission for copying of this thesis in any manner, in whole or in part, for scholarly purposes may be granted by the professor or professors who supervised my thesis work or, in their absence, by the Head of the Department in which my thesis work was done. It is understood that any copying or publication or use of this thesis or parts thereof for financial gain shall not be allowed without my written permission. It is also understood that this copy is being made available in this form by the authority of the copyright owner solely for the purpose of private study and research and may not be copied or reproduced except as permitted by the copyright laws without written authority from the copyright owner. 


\begin{abstract}
Disulfiram (DSF) is a sulphur-containing compound and has been used to treat chronic alcoholism and cancer for decades. DSF inactivates aldehyde dehydrogenase (ALDH) by modifying its cysteine residue(s). ALDH is recently identified as a cancer stem cell marker, facilitating cell self-renewal and tumour-initiating capacity. Hydrogen sulphide $\left(\mathrm{H}_{2} \mathrm{~S}\right)$ as a new gasotransmitter regulates various cellular functions by the $S$-sulfhydration of cysteine residues in target proteins. $\mathrm{H}_{2} \mathrm{~S}$ has also been shown to exhibit similar properties to DSF in the sensitization of cancer cells to chemotherapeutic agents. Here, the potential of DSF as a $\mathrm{H}_{2} \mathrm{~S}$-releasing donor under various conditions was investigated and the roles of $\mathrm{H}_{2} \mathrm{~S}$ in the DSF-mediated inhibition of ALDH activity and decrease in cell viability in liver cancer cells were also examined. It was demonstrated that DSF facilitated $\mathrm{H}_{2} \mathrm{~S}$ release from thiol-containing compounds, and DSF and $\mathrm{H}_{2} \mathrm{~S}$ were both capable of regulating ALDH through inhibition of gene expression and enzymatic activity. The supplement of $\mathrm{H}_{2} \mathrm{~S}$ sensitized human liver cancer cells (HepG2) to DSF induced reduction in cell viability. The expression of cystathionine gamma-lyase (a major $\mathrm{H}_{2} \mathrm{~S}$-generating enzyme) was lower but ALDH was higher in mouse liver cancer stem cells (Dt81Hepa1-6) in comparison with their parental cells (Hepa1-6), and $\mathrm{H}_{2} \mathrm{~S}$ was able to inhibit liver cancer stem cell adhesion. In conclusion, these data provide some clues for combining with DSF and $\mathrm{H}_{2} \mathrm{~S}$ for inhibition of cancer cell growth and tumour development by targeting ALDH.
\end{abstract}

Key words: Disulfiram, $\mathrm{H}_{2} \mathrm{~S}$, Cystathionine gamma-lyase, Aldehyde dehydrogenase, Liver cancer stem cells 


\author{
2-Me: 2-mercaptoethanol \\ 3-MST: 3-Mercaptopyruvate sulfurtransferase \\ ALDH: Aldehyde dehydrogenase \\ CBS: Cystathionine $\beta$-synthase \\ CO: Carbon monoxide \\ CSC: Cancer stem cell \\ CSE: Cystathionine gamma-lyase \\ CSE-KO: CSE knockout \\ DDC: diethyldithiocarbamate \\ DDC-Cu: Diethyldithiocarbamate copper complex \\ DSF: Disulfiram \\ DTT: Dithiothreitol
}

Abbreviations

GSH: Glutathione

$\mathrm{H}_{2} \mathrm{O}_{2}$ : Hydrogen peroxide

$\mathrm{H}_{2} \mathrm{~S}$ : Hydrogen sulphide

MDR: Multi drug resistance

MTT: 3-((4,5)-dimethylthiazol-(2)-yl)-2,5-diphenyltetrazolium bromide

$\mathrm{Na}_{2} \mathrm{~S}_{3}$ : Sodium trisulphide

NaHS: Sodium hydrosulphide

NO: Nitric oxide

P5P: Pyridoxal 5'-phosphate

$\mathrm{PbAc}_{2}$ : Lead Acetate 
ROS: Reactive oxygen species

WT: Wild-type 


\section{Acknowledgements}

I would like to thank my supervisor, Dr. Guangdong Yang, for his guidance throughout this project. Despite the uncertainty imposed by both the pandemic and insolvency of the university, he has continued to provide encouragement and support. Thank you for providing me with the tools and encouragement needed to complete this degree. Without your knowledge and expertise, I would not have been able to accomplish this. Thank you to my committee members, Drs. Eric Gauthier and Sabine Montaut, for their insight and thoughtful suggestions which helped me to complete this project and my degree.

I would also like to extend my gratitude to all of the members of the CMRU. Each and every day, there was always someone willing to lend a helping hand with protocols or troubleshooting. Specials thanks to Drs. Ming Fu and Yuehong Wang in particular, for all their help in fixing troublesome western blots. With the turmoil of the pandemic and insolvency, I am extremely grateful to have worked with the wonderful people at the CMRU, who helped me through this difficult time.

Lastly, thank you to my friends and family, who have supported me through this endeavour, and thank you to Danielle, for being with me through all of this. 


\section{Table of Contents}

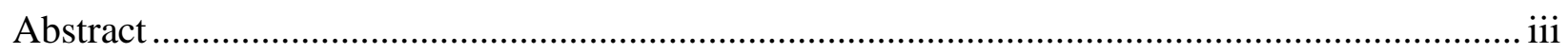

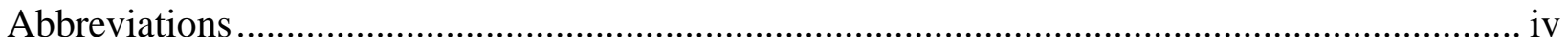

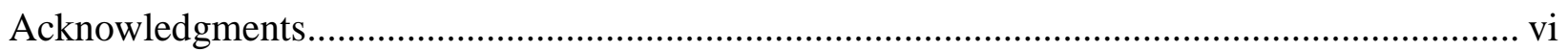

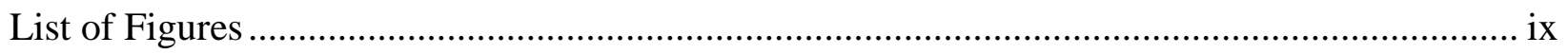

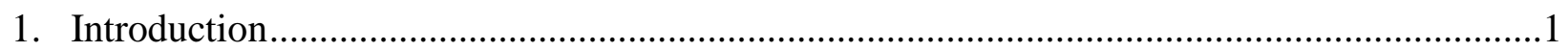

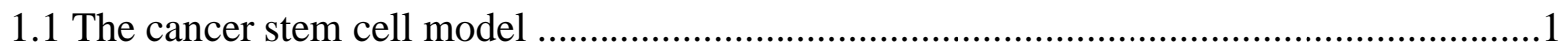

1.2 Aldehyde dehydrogenase as a CSC marker ............................................................2

1.3 Disulfiram (DSF) as an ALDH-inhibiting CSC treatment ..........................................5

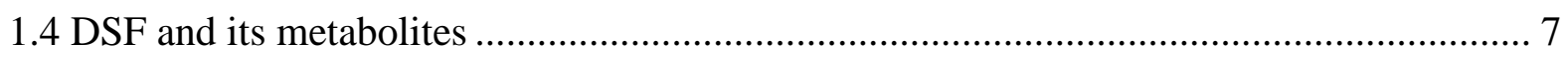

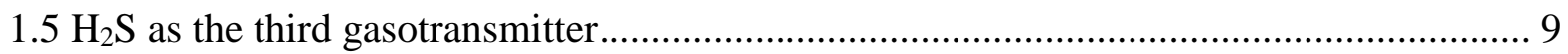

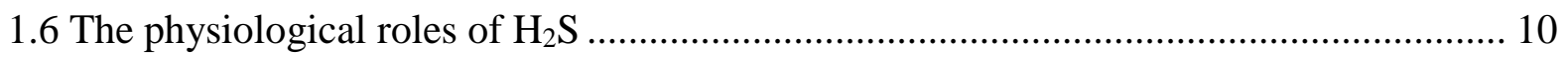

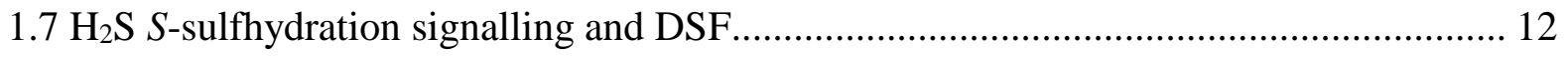

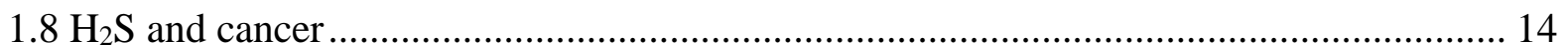

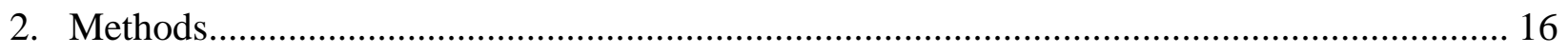

2.1 Cell culture ................................................................................................... 16

2.2 Cell survival ................................................................................................. 16

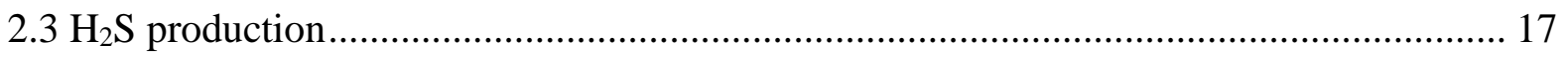

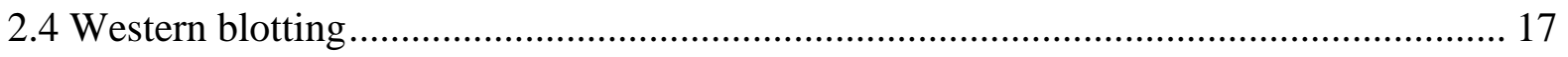

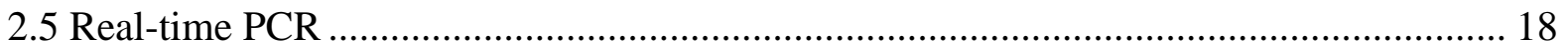

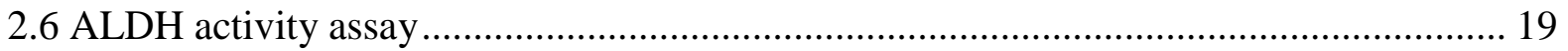

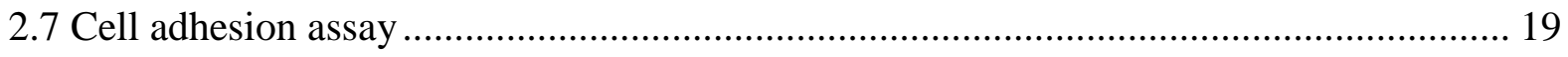




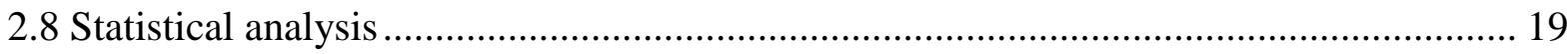

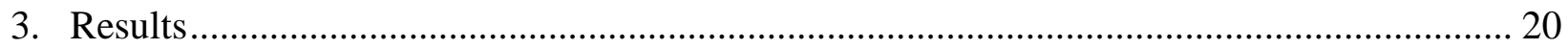

3.1 DSF reacts with thiol-containing compounds under physiological conditions ............... 20

3.2 DSF stimulates $\mathrm{H}_{2} \mathrm{~S}$ release in mouse liver tissues.................................................... 24

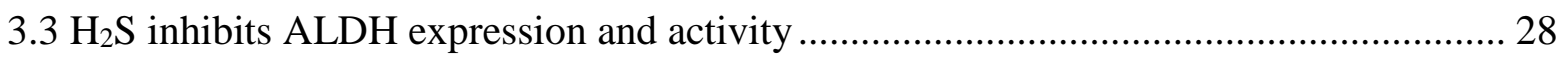

3.4 $\mathrm{H}_{2} \mathrm{~S}$ sensitizes DSF-inhibited cell viability and inhibits CSC adhesion ......................... 31

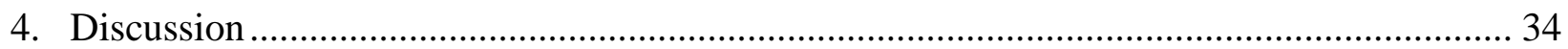

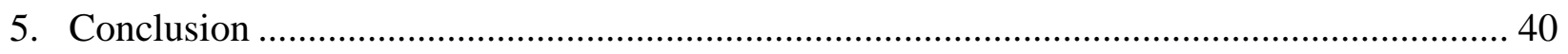

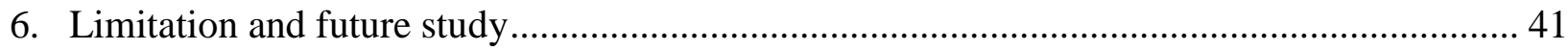

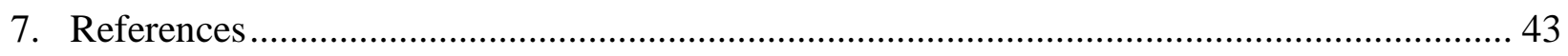




\section{List of Figures}

Figure 1 Chemotherapy and radiotherapy resistance in ALDH expressing cells (Adapted from

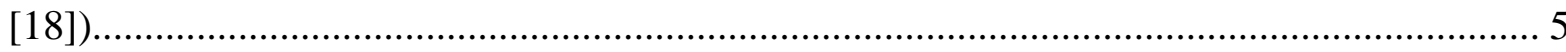

Figure 2 Structural composition of DSF, DDC, and the DDC-Cu complex ................................. 9

Figure 3 Endogenous production and functions of $\mathrm{H}_{2} \mathrm{~S}$ (Adapted from [63]) …........................ 12

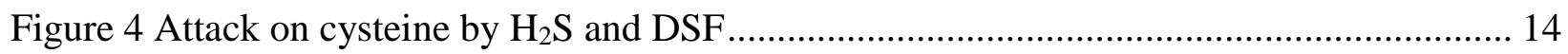

Figure 5 DSF reacts with thiol-containing compounds under physiological conditions .............. 21

Figure 6 The effects of $\mathrm{Cu}^{2+}$, $\mathrm{pH}$ and temperature on $\mathrm{H}_{2} \mathrm{~S}$ release from DSF-GSH interaction .. 23

Figure 7 DSF stimulated $\mathrm{H}_{2} \mathrm{~S}$ production in WT mouse liver lysate ........................................ 25

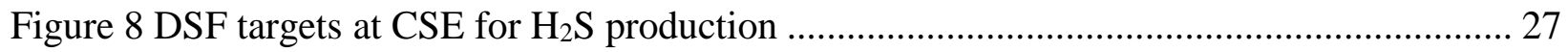

Figure $9 \mathrm{DSF}$ and $\mathrm{H}_{2} \mathrm{~S}$ inhibit the expression and activity of ALDH ....................................... 29

Figure 10 Deficiency of CSE promotes the expression and activity of ALDH........................... 30

Figure $11 \mathrm{H}_{2} \mathrm{~S}$ sensitizes DSF-inhibited cell viability and inhibits CSC adhesion....................... 32

Figure12 The proposed pathways for DSF-CSE- $\mathrm{H}_{2} \mathrm{~S}$ interactions and their combinational effects

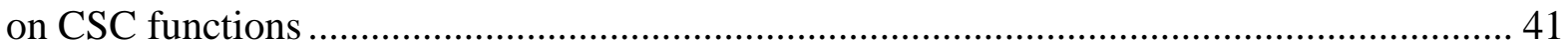




\section{Introduction}

\section{$1.1 \quad$ The cancer stem cell model}

One of the greatest hurdles facing modern medicine is the development of adequate strategies to combat cancer relapse. Our capacity to wholly eradicate some types of cancer is severely lacking, resulting in high relapse rates, often accompanied by more aggressive, chemotherapy resistant tumours ${ }^{1}$. While difficulties in early detection and the tissue of origin can contribute to these high rates, a major contributor is poor understanding of cancer development. Relapse is not typically due to the emergence of a new cancer from a separate series of mutations, but rather from the more robust cells, capable of withstanding the prescribed chemotherapeutic regime, surviving and forming novel tumours ${ }^{2}$. It is these few cells which are becoming of greater interest in recent decades, and it is hoped that by targeting them, relapse will become a relic of the past.

The theory that describes these cells is known as the cancer stem cell (CSC) model. The CSC model postulates that the majority of cancer replication, proliferation, and differentiation is driven by a select subpopulation of a tumour which possess increased stem cell-like properties ${ }^{2}$. These CSCs display several characteristics which are undesirable for treatment, such as higher migration, colony formation, and replication, and they often possess innate multi-drug resistance (MDR) ${ }^{2}$. These characteristics allow CSCs to be uniquely capable of surviving chemotherapy and generating novel tumours which are more aggressive and resistant to treatment.

This idea of a few cells driving cancer progression first gained traction in the 1990s when Lapidot et al. successfully transplanted acute myeloid leukemia cells from human patients into 
mice, and selectively showed that $\mathrm{CD} 34^{+} \mathrm{CD} 38^{-}$cells, while consisting of only a small subset of the population, were the only cells capable of establishing disease ${ }^{3}$. These findings have been replicated under various models and tissues, consistently showing that by selecting cells with stem cell properties, the number of cells required to successfully transplant cancer can be reduced by several orders of magnitude ${ }^{4}$.

The formation of a tumour is the result of unregulated cell growth, but the process through which this occurs closely mimics that of ordinary tissue development ${ }^{2}$. The commonly understood features of tissue development, that being the replication of a few stem cells which differentiate to form a phenotypically diverse cell population, can be applied to cancer development ${ }^{5}$. This positions CSCs as the primary focus in developing novel chemotherapeutics. CSC theory postulates that by selectively targeting at such tumour-initiating cells during treatment, the selfrenewing core of a tumour will be eliminated, improving the chance of complete cancer elimination ${ }^{4}$. Combining CSC targeting with traditional anti-cancer treatments may therefore eliminate the entire cancer population in a more efficient manner.

\subsection{Aldehyde dehydrogenase as a CSC marker}

In order to target CSCs for treatment, effective methods of identifying and confirming the presence of these cells are needed. CSCs have been identified in practically every tissue, including skin, liver, brain, and breast ${ }^{6-9}$. Initially, these highly tumorigenic cells are isolated by the expression of select cell-surface markers, such as CD133 ${ }^{10}$. Over the years, however, highly tumorigenic cells have undergone full proteomic analysis, and a large selection of CSC marker proteins have emerged. 
CSC markers are not inherently bad, as many of these proteins, signal transducers and transcription factors are associated with the increased proliferation seen in early development of tissues and ordinary stem cells ${ }^{10}$. Overexpression of these markers without proper regulation, however, results in the uncontrolled growth and expansion of cancer. CSC markers serve two functions as targets for treatment: these proteins are over-expressed, allowing for selective therapies with improved on-site effects; and these proteins are often the cause of aggressive behaviour, so by targeting them the rapid proliferation of the tumour is reduced. One issue with targeting CSC markers is that these treatments may inadvertently affect the function of ordinary stem cells, so potential side-effects should be taken into account ${ }^{11}$.

The use of full proteomic screening in clinical settings to determine the aggressiveness of a given tumour is becoming a widely-adopted practice ${ }^{12}$. By examining the number of CSC markers and their composition, physicians can provide better prognosis and treatment options, as higher CSC numbers are associated with poorer patient outcomes ${ }^{13}$. Several of the key CSC markers are activators of self-renewal and division, such as Notch, Wnt, and Hedgehog ${ }^{14}$. These are some of the most commonly over-expressed signalling pathways in CSCs, and are often the targets of experimental treatments. Another emergent CSC marker is the alcohol-metabolizing, aldehyde dehydrogenase $(\mathrm{ALDH})^{15}$.

ALDH is an $\mathrm{NAD}(\mathrm{P})^{+}$dependent enzyme which catalyzes the oxidation of aldehydes to their relatively non-toxic carboxylic acids, the most notable of which is acetaldehyde, a product of alcohol metabolism. Several ALDH isozymes have been implicated as CSC markers, including ALDH1A1 in ovarian, breast, and liver cancer, or ALDH1A3 in colon and lung cancers ${ }^{14,16}$. While 
the various ALDH isozymes serve different functions based on differential tissue or cellular localization, practically all isozymes have been identified as potential CSC markers ${ }^{16}$. Overexpression of these ALDH isozymes is associated with increased resistance to both chemo- and radio-therapy ${ }^{17}$. In fact, ALDH alone promotes both self-renewal and MDR within cancer cells.

ALDH confers stemness properties through several interlinked mechanisms. ALDH promotes MDR primarily through its catalytic activity. ALDH is responsible for converting aldehydes to carboxylic acids, reducing the likelihood of aldehyde-DNA/protein adducts, which disrupt metabolism and cell cycle and result cell death ${ }^{18}$. This is particularly note-worthy, as most cancer treatments, including both chemo- and radio-therapy, rely on the generation of reactive oxygen species (ROS). By increasing ALDH expression, CSCs are able to tolerate a significantly higher oxidative burden, without suffering the same levels of DNA and protein disruption (Fig. 1) 18,19. It has also been proposed that ALDH may directly metabolize chemotherapeutics, inactivating drugs such as cyclophosphamide, paclitaxel and doxorubicin before they can fulfill their intended purpose ${ }^{20,21}$. Due to these robust MDR mechanisms, ALDH expressing cell lines are resistant to several common chemotherapies, including etoposide, cisplatin, and fluorouracil 22. In addition to conferring MDR, ALDH is also indirectly involved in promoting CSC selfrenewal. ALDH acts non-enzymatically to stabilize Gli2, a transcription factor that promotes the expression of Hedgehog ${ }^{23}$. Gli2 stabilization results in increased transcription of Hedgehog, thereby promoting cell proliferation and replication.

While the importance of ALDH as a CSC marker should not be over-stated, the overexpression of ALDH appears to act as an all-in-one activator of CSC properties. ALDH confers a 
great deal of stemness to cancer cells, drastically improving their resistance to chemo- and radiotherapy, and promotes Hedgehog to drastically increase self-renewal. High ALDH activity alone is a sufficient marker to select for populations with enhanced tumorigenic potential, even when compared to other CSC markers such as CD133 ${ }^{24}$. The absence of ALDH in CD133 cells dramatically reduces tumorigenicity in xenograft models, implicating ALDH as an ideal target for CSC treatment.
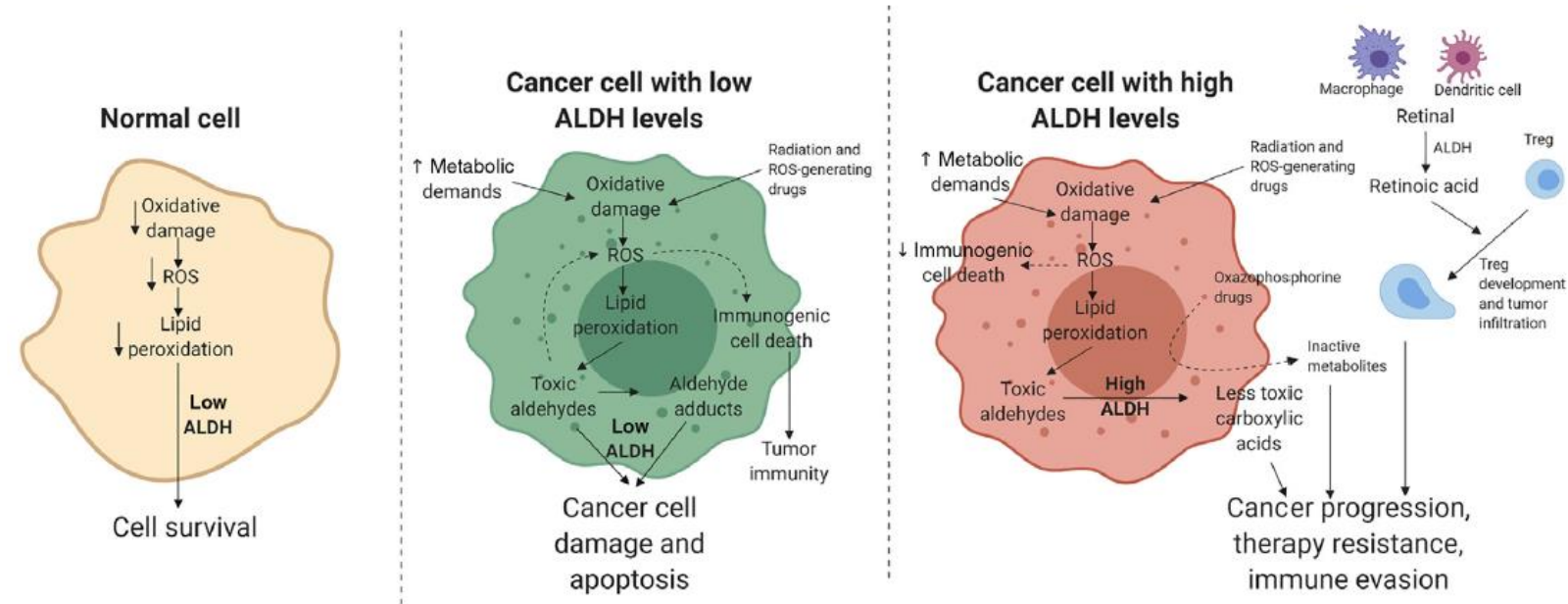

Figure 1. Chemotherapy and radiotherapy resistance in ALDH-expressing cells (Adapted from [18])

\subsection{Disulfiram (DSF) as an ALDH-inhibiting CSC treatment}

Liver is one of the largest ALDH-expressing tissues, with many isoforms being highly expressed ${ }^{25}$. While ALDH is expressed across all tissues, particularly during development, the liver is one of few tissues which continues to increase ALDH expression with age ${ }^{26,27}$. The increased expression is likely due to the liver's function as the primary site of metabolic activity. For decades, ALDH has been understood primarily as the second enzyme in ethanol metabolism, 
as it facilitates the conversion of acetaldehyde into acetate ${ }^{28,29}$. Owing to this role, ALDH inhibition has been used in clinics for years, not as a treatment for cancer, but for alcoholism.

Disulfiram (DSF), marketed under the name Antabuse, has been used in the treatment of alcoholism since the $1960 \mathrm{~s}^{30}$. DSF works as an 'alcohol aversion' drug; alcohol consumption, after taking DSF, leads to highly unpleasant symptoms, such as nausea, headaches, and extreme discomfort ${ }^{31}$. The DSF-ethanol reaction has been likened to a severe and immediate hangover. As a result, its use was implemented in the treatment of alcoholism, with the intent to dissuade patients from taking alcohol out of fear of the DSF-ethanol reaction. Unfortunately, DSF suffers from relatively poor success rates, as patients often refuse to continue treatment and its use in alcohol aversion has declined in recent years ${ }^{32}$. With the emergent role of ALDH as a CSC marker, a newlease on life has appeared for the drug, in the form of anti-cancer treatment.

DSF is effective at treating cancer as an independent therapy. The administration of DSF alone is capable of inducing apoptosis in several tissues, including breast, embryonal cell lines, skin, pancreas, and lung ${ }^{33-37}$.While DSF alone has potential as an anti-cancer drug, it drastically improves the sensitivity of MDR-cell lines to multiple chemotherapies. Drugs such as taxol, cisplatin, paclitaxel, and even radiation therapy are potentiated by co-treatment with DSF ${ }^{17,33,38,39}$. Inhibition of ALDH by DSF is an irreversible process, involving the blockage of the active site and a decrease in catalytic activity, and ultimately leads to protein degradation and decreased ALDH expression. The result is an increase in the toxicity of ROS and a decrease in the activation of ALDH/Hedgehog signalling ${ }^{23}$. Using DSF as a cancer treatment allows physicians to target CSC functionality on multiple fronts. 
Alongside DSF, several other ALDH inhibiting compounds have been tested for their ability to act as anti-cancer agents. Novel drugs such as CM37 are effective at inducing ROS and DNA damage in ovarian cancer cells ${ }^{40}$, and eugenol enhances anti-cancer activity of cisplatin ${ }^{41}$. Despite these successes, the suitability for these developmental drugs, and even DSF, can be limited in clinical use. Limited bioavailability or off-site toxicity of these compounds could limit their use as novel chemotherapeutics ${ }^{18}$. While DSF is relatively non-toxic, several cases of stress-test validated DSF-induced hepatitis have been reported ${ }^{42,43}$. Therefore, the development of novel drugs which mimic DSF's inhibitory effects while simultaneously reducing patient risk is of utmost importance.

\subsection{DSF and its metabolites}

DSF inhibits ALDH by binding to cysteine residues within the active site, though the exact mechanism is unknown. However, it is commonly agreed that DSF reacts with and binds to cysteine 302 , which is essential for catalytic activity ${ }^{44}$. This results in competitive inhibition, as substrates are unable to enter the site, and the covalent linkage that is formed is irreversible, resulting in protein degradation ${ }^{45}$. Several mechanisms for this reaction have been proposed, as multiple DSF metabolites are known to inhibit ALDH. DSF itself is not bioavailable, as it is rapidly converted into diethyldithiocarbamate (DDC), once in the bloodstream, reducing the likelihood that it is the active compound (Fig. 2) ${ }^{46}$. Analysis of cysteine 302 bound molecules after DSF treatment show metabolites diethylthiocarbamic acid methyl ester (Me-DTC) and Me-DDC from DDC as the inhibiting compounds ${ }^{47}$. However, DSF treatment of purified ALDH in vitro, also 
shows complete inhibition. All these evidence suggest that ALDH inhibition can occur by multiple DSF-derived compounds ${ }^{48}$.

The stabilization of DDC through binding with $\mathrm{Cu}^{2+}$ results in the formation of the DDC-Cu complex (Fig. 2). DDC-Cu forms spontaneously when DSF and $\mathrm{Cu}^{2+}$ are mixed, showing greater effect as an ALDH inhibitor and cancer treatment ${ }^{49,50}$. The increase in toxicity towards cancer cells is attributed to increased DSF activity, allowing DSF to more effectively inhibit ALDH. The stabilization of DDC by $\mathrm{Cu}^{2+}$ is believed to increase its metabolism to its active forms. However, the DDC-Cu complex also increases $\mathrm{Cu}^{2+}$ uptake, resulting in higher $\mathrm{Cu}^{2+}$ levels which may account for the greater toxicity seen in cancer cells ${ }^{51,52}$. The stability of the DDC-Cu complex also promotes the formation of non-polar compounds, which may increase DSF uptake by cells, as DDC present within the bloodstream is likely to be absorbed at a much slower rate (Fig. 2).

The novel role of DSF as an anticancer agent has renewed interest in the mechanisms and efficacy of the drug in ALDH inhibition. The discovery of a more effective therapeutic agent which mimics the cysteine-binding properties of DSF could dramatically improve our capacity to treat aggressive cancer.

Figure 2. Structural composition of DSF, DDC, and the DDC-Cu complex 


\section{5 $\quad \mathrm{H}_{2} \mathrm{~S}$ as the third gasotransmitter}

Cell signalling is a complex and diverse system which allows cells to respond and adapt to both external and internal stressors. The molecules which drive the signalling processes are varied in structure and function, and include amino acids, saccharides, hormones, and the relatively novel gasotransmitters. Gasotransmitters are an emergent class of signalling molecule, broadly defined as any endogenously generated gaseous molecule involved in the propagation of cellular signals

${ }^{53}$. The classification currently encompasses three molecules, those being carbon monoxide (CO), nitric oxide (NO), and the most recently added hydrogen sulphide $\left(\mathrm{H}_{2} \mathrm{~S}\right)^{54}$.

Gasotransmitters are unique in their role in propagating signalling processes. Unlike traditional signalling compounds, gasotransmitters are not restricted to dedicated receptors. Gasotransmitters directly alter proteins through post translational modification, immediately triggering effects on metabolism, catabolism, and transcription ${ }^{55}$. With the discovery of the signalling properties of $\mathrm{H}_{2} \mathrm{~S}$, Wang proposed the termed 'gasotransmitter' to identify this novel class of molecules ${ }^{56}$. Since this recognition, a novel field of cell signalling has emerged around uncovering the complexities of gasotransmitter signalling. The criteria for gasotransmitter classification, as outlined by Wang, are summarized here: in order to be classified as a gasotransmitter, the molecule in question must be a small gaseous molecule which is freely permeable to membranes. The gas must be endogenously produced by a well-regulated metabolic system. The gas must possess well-defined functions on a physiological level, with specific cellular and molecular targets. Lastly, the effects of said gas must be reproducible by exogenous application of the same molecule ${ }^{53}$. To date, only three molecules have been accepted as 
gasotransmitters, but ongoing work suggests that there may be several others, such as ammonia and methane, although these have yet to be accepted by the wider community ${ }^{53,55}$.

Research on the physiological effects of $\mathrm{H}_{2} \mathrm{~S}$ has traditionally been conducted through the lens of our historical understanding of the gas; $\mathrm{H}_{2} \mathrm{~S}$ is a toxic, foul-smelling gas which is feared for its lethality ${ }^{54}$. The toxicity of $\mathrm{H}_{2} \mathrm{~S}$ is primarily attributable to its potent binding of cytochrome $\mathrm{C}$ oxidase and inhibiting cellular respiration in a cyanide-like manner ${ }^{57}$. When $\mathrm{H}_{2} \mathrm{~S}$ was first discovered in mammalian tissue in the 1960s, it was believed to be metabolic waste as a by-product of some other systems. With the discovery of gasotransmitters in the late $20^{\text {th }}$ century, however, renewed interest in the gas emerged, and it was discovered that $\mathrm{H}_{2} \mathrm{~S}$ is an essential component of maintaining physiological health ${ }^{58}$.

\subsection{The physiological roles of $\mathrm{H}_{2} \mathrm{~S}$}

The endogenous production of $\mathrm{H}_{2} \mathrm{~S}$ involves several enzymatic pathways, each of which being found in selective tissue and organs. $\mathrm{H}_{2} \mathrm{~S}$ production is mediated by three known pathways denoted by the primary enzyme involved; cystathionine $\gamma$-lyase (CSE), cystathionine $\beta$-synthase (CBS), and 3-mercaptopyruvate sulfurtransferase (3-MST) (Fig. 3) ${ }^{59}$. CBS is the most prominent $\mathrm{H}_{2} \mathrm{~S}$-producing enzyme within the brain, while CSE plays the largest role in the other major tissues; 3-MST plays a secondary or tertiary role in most tissues ${ }^{54,60}$. In the liver in particular, CSE accounts for approximately $90 \%$ of all $\mathrm{H}_{2} \mathrm{~S}$ production ${ }^{60}$. Given that the liver is one of the largest $\mathrm{H}_{2} \mathrm{~S}$ producing organs, this highlights the importance of CSE in maintaining hepatocellular health 61. 
The physiological functions of the third gasotransmitter include regulation of cellular senescence, cell cycle, metabolism, autophagy, and oxidative stress (Fig. 3) ${ }^{62,63}$. The effects of cellular regulation have wide reaching effects on the physiological functions of tissues, including vasorelaxation, reducing atherosclerosis, preventing ischemia-reperfusion injury, and regulating lipid metabolism within the liver ${ }^{64-67}$. Many of the effects of $\mathrm{H}_{2} \mathrm{~S}$ on a physiological scale have been attributed to its anti-oxidant properties. $\mathrm{H}_{2} \mathrm{~S}$ can reduce oxidative stress by either directly reacting with the ROS, as $\mathrm{H}_{2} \mathrm{~S}$ is a reducing agent, or by promoting the transcription of the antioxidant response element, thereby increasing levels of anti-oxidant enzymes such as super oxide dismutase ${ }^{68-70}$. While $\mathrm{H}_{2} \mathrm{~S}$ mediates these effects by altering complex systems such as inflammation or cell cycle, the core molecular mechanism, $S$-sulfhydration, is strikingly similar to the mechanistic function of DSF.

Figure 3. Endogenous production and functions of $\mathrm{H}_{2} \mathrm{~S}$ (Adapted from [63]) 


\subsection{S-Sulfhydration signalling and DSF}

$\mathrm{H}_{2} \mathrm{~S}$ is capable of signalling through a few mechanisms, though by far the most prominent and effective is through $S$-sulfhydration (alternatively sulfhydration or persulfidation) ${ }^{62,71} \cdot \mathrm{H}_{2} \mathrm{~S}$ reacts with cysteine residues within proteins, leading to the formation of a persulfide group (Fig. $\mathbf{4 A}$ ). The formation of the persulfide increases the reactivity of the cysteine, and can result in increased catalytic activity or the formation of disulphide bonds, completely altering the function of the protein ${ }^{71,72}$. The exact nature of $S$-sulfhydration is not known. From a chemical perspective, $\mathrm{H}_{2} \mathrm{~S}$ cannot spontaneously react with cysteine to yield a persulfide group. Several intermediate steps have been proposed to explain this discrepancy. The most likely mechanism would be the formation of a polysulfide chain in solution, which is then capable of reacting with cysteine ${ }^{71,73}$. The ubiquity of cysteine residues in proteins, ranging from structural disulfide bridges to catalytic sites, ensures that $\mathrm{H}_{2} \mathrm{~S}$ has wide ranging effects on many proteins.

$S$-sulfhydration by $\mathrm{H}_{2} \mathrm{~S}$ is known to regulate a great number of proteins with varied functions. Some examples include the $S$-sulfhydration of GAPDH, increasing activity and metabolism; NMDA receptors in the nervous system, increasing their activity and long-term potentiation; SIRT1, increasing expression and cell survival; actin, increasing polymerization and regulating cell cycle; and antibodies, decreasing binding and effectiveness ${ }^{62,74-77}$. With such broad functions in established targets of $S$-sulfhydration, there is continued interest in uncovering as-of-yet unknown targets of $\mathrm{H}_{2} \mathrm{~S}$.

The similarity between DSF-mediated inhibition of ALDH and $S$-sulfhydration is evident. Both compounds, DSF and $\mathrm{H}_{2} \mathrm{~S}$, target thiol groups of proteins to alter function (Fig. 4). The 
sulphur atoms present in the dithiocarbamate groups of DSF and DDC suggest that a similar mechanism of action may exist between DSF and $\mathrm{H}_{2} \mathrm{~S}$.

\section{Figure 4. Attack on cysteine by $\mathrm{H}_{2} \mathrm{~S}$ and DSF}

\section{8 $\mathrm{H}_{2} \mathrm{~S}$ and cancer}

$\mathrm{H}_{2} \mathrm{~S}$ and its role in cancer development and treatment is an expanding field of research ${ }^{78}$. $\mathrm{H}_{2} \mathrm{~S}$ donors are able to selectively kill cancer cell lines from multiple tissues, without harming 'normal', noncancerous cell lines ${ }^{79} \cdot \mathrm{H}_{2} \mathrm{~S}$ alone may act to selectively target cancer without inducing off-site toxicity, which is a significant concern when using traditional chemotherapies. Additionally, the use of $\mathrm{H}_{2} \mathrm{~S}$-releasing doxorubicin resulted in a drastic increase in cancer cell death, while also reducing weight loss and cardiotoxicity in mice ${ }^{80} . \mathrm{H}_{2} \mathrm{~S}$ can both selectively target cancer cells to reduce survival, but when administered with traditional chemotherapy, can reduce the toxic side-effects due to off-site toxicity. 
Our lab previously reported a novel mechanism for $\mathrm{H}_{2} \mathrm{~S}$ to combat cancer, specifically against MDR cells. It was found that $\mathrm{H}_{2} \mathrm{~S}$ inhibits drug efflux, thereby sensitizing MDR cells to treatment with doxorubicin ${ }^{81}$. Promoting the accumulation of traditional chemotherapies is an effective method to target MDR cells, but there is reason to believe that $\mathrm{H}_{2} \mathrm{~S}$ targets MDR cancer cells through a novel mechanism.

$S$-sulfhydration of cysteine residues is the connecting ties among $\mathrm{H}_{2} \mathrm{~S}$, DSF, and ALDH. The remarkable similarities in the mechanism of action between DSF and $\mathrm{H}_{2} \mathrm{~S}$ suggest that the two compounds share molecular targets. With the large roles that both ALDH and $\mathrm{H}_{2} \mathrm{~S}$ play in maintaining hepatocellular health, and the metabolism and activity of DSF within the liver, we speculate that interactions between $\mathrm{H}_{2} \mathrm{~S}$ and DSF/ALDH may occur ${ }^{23,62,82}$. With the established role of $\mathrm{H}_{2} \mathrm{~S}$ in cancer, acting to sensitize MDR tumours and regulate proliferation, we hypothesize that $\mathrm{H}_{2} \mathrm{~S}$ can regulate these factors through ALDH. Limited work shows $\mathrm{H}_{2} \mathrm{~S}$ may function as an ALDH inhibitor, and here we build upon and expand current understanding of the effects of $\mathrm{H}_{2} \mathrm{~S}$ on ALDH activity and expression within liver ${ }^{83}$.

The capacity for $\mathrm{H}_{2} \mathrm{~S}$ to circumvent chemotherapy resistance and the potential role of $\mathrm{H}_{2} \mathrm{~S}$ as an inhibitor of ALDH indicate that $\mathrm{H}_{2} \mathrm{~S}$ may be an effective method to target CSC populations. Given the similarities between DSF and $\mathrm{H}_{2} \mathrm{~S}$, in this thesis, I examined the capacity of DSF to function as a $\mathrm{H}_{2} \mathrm{~S}$ donor under various physiological conditions, and for $\mathrm{H}_{2} \mathrm{~S}$ to function as a novel inhibitor of ALDH in liver. We also assessed the interaction of DSF and $\mathrm{H}_{2} \mathrm{~S}$ metabolism in mouse liver lysate, and determined the regulatory role of ALDH and $\mathrm{H}_{2} \mathrm{~S}$ in liver cancer growth and CSC function. 


\section{Methods}

\subsection{Cell culture}

Human liver cancer HepG2 cells (American Type Culture Collection, Manassas, VA), mouse liver cancer Hepa1-6 cells, and mouse liver CSC Dt81 Hepa1-6 cells were cultured in Dulbecco's Modified Eagle's Medium (Thermo Fisher Scientific, Ottawa, ON) supplemented with $10 \%$ fetal bovine serum, $100 \mathrm{U} / \mathrm{mL}$ penicillin, and $100 \mu \mathrm{g} / \mathrm{mL}$ streptomycin at $37^{\circ} \mathrm{C}$ with a humidified atmosphere of 5\% $\mathrm{CO}_{2}{ }^{65,81}$. The Dt81 Hepa1-6 CSCs were derived from the in vivo passage of Hepa1-6 cells in C57BL/6 mice and were selected for enhanced tumorigenicity and higher expressions of CSC marker proteins ${ }^{84}$. The cells were grown to $70-80 \%$ confluence and then subjected to various treatments. For treatment with DSF and/or $\mathrm{H}_{2} \mathrm{~S}$, the cells were washed once and changed to fresh medium containing the appropriate concentration of NaHS. After 30 minutes of incubation, DSF was then added, and cells were incubated for an additional 24 hours before collection.

\subsection{Cell survival}

The effects of independent and co-treatment with DSF and $\mathrm{H}_{2} \mathrm{~S}$ on cell viability were determined using 3-((4,5)-dimethylthiazol-(2)-yl)-2,5-diphenyltetrazolium bromide (MTT) assay as described before ${ }^{65,81}$. Briefly, 20,000 cells were seeded per well in a 96-well plate and grown to $70-80 \%$ confluence. After 24 hours of treatment, $0.5 \mathrm{mg} / \mathrm{mL}$ MTT solution was added in serumfree medium for 4 hours at $37^{\circ} \mathrm{C}$. The resultant formazan precipitate was dissolved in $100 \mu \mathrm{L}$ 
dimethyl sulfoxide, and Absorbance was measured at $570 \mathrm{~nm}$ using FLUOstar OPTIMA microplate spectrophotometer (BMG Labtech, Germany). Treatment groups were normalized to untreated control cells. To further support the MTT data, cell count was conducted on each group using a Neubauer hemocytometer.

\section{$2.3 \mathrm{H}_{2} \mathrm{~S}$ production}

$\mathrm{H}_{2} \mathrm{~S}$ production was measured using the lead acetate $\left(\mathrm{PbAc}_{2}\right)$ method ${ }^{85}$. Briefly, reagents were mixed at the indicated concentrations in phosphate buffered saline (PBS), and then added to 96-well plates. $\mathrm{PbAc}_{2}$ paper (Sigma-Aldrich, Oakville, ON) was placed over the wells, and the solution was allowed to incubate for 2 hours at $37^{\circ} \mathrm{C} . \mathrm{H}_{2} \mathrm{~S}$ released from solution reacted with the paper to form lead sulphide precipitate with a brown color. For detection of enzymatic $\mathrm{H}_{2} \mathrm{~S}$ release in liver tissues by DSF, an equal amount of mouse liver lysates was mixed with cysteine (10 mM), pyridoxal 5'-phosphate (P5P, $2 \mathrm{mM})$, and/or DSF $(0-100 \mu \mathrm{M})$ in 96-well plates, and $\mathrm{PbAc} 2$ paper was placed over the wells. The reaction was incubated for 2 hours at $37^{\circ} \mathrm{C}$ in the dark. The intensity of the lead sulphide formed on the lead acetate paper was quantified with the Image $\mathbf{J}$ software, and the amount of $\mathrm{H}_{2} \mathrm{~S}$ release was calculated based on a NaHS standard.

\subsection{Western blotting}

Western blotting was conducted as described elsewhere ${ }^{65}$. Briefly, the cells or mouse liver tissues were collected and lysed in Tris-EDTA sucrose buffer (50 mMTris-HCl, 0.53 mM EDTA, $20 \% \mathrm{w} / \mathrm{v}$ sucrose $\mathrm{pH} 7.2$ ) in the presence of protease inhibitors (Sigma-Aldrich). Supernatant was extracted by centrifugation at $14,000 \mathrm{rpm}$ for 15 minutes at $4^{\circ} \mathrm{C}$. The Bicinchoninic acid assay (Thermo Fisher Scientific) was used to determine protein concentrations. Equal amount of protein 
was mixed with loading buffer and boiled for 5 minutes before being loaded into SDS-PAGE gel. After running, protein samples were transferred to PVDF membrane (Pall Corporation, Pensacola, FL). Membranes were blocked with PBS supplemented with 3\% non-fat milk and $0.1 \%$ tween 20 for 30 minutes at room temperature. Afterwards, the membranes were incubated with primary antibody overnight at $4^{\circ} \mathrm{C}$. Membranes were washed multiple times, then incubated with secondary antibody for 1.5 hours at room temperature followed by detection of chemiluminescent signal with ECL (Bio-Rad Laboratories, Mississauga, ON). The dilutions of primary antibodies were as follows: CSE (1:1000, Abnova, Taipei), ALDH (1:1000, Cell Signaling Technology, Danvers, MA), GAPDH (1:1000, Santa Cruz Biotechnology Inc, Santa Cruz, CA), and $\beta$-actin (1:5000, Sigma-Aldrich).

\subsection{Real-time PCR}

Total RNAs from HepG2 cells or mouse liver tissue was extracted using TRIReagent (Thermo Fisher Scientific) and cDNA was prepared using Maxima H Minus First Strand cDNA Synthesis Kit (Thermo Fisher Scientific). All samples were run in triplicate, and relative gene expression was calculated as $2^{-\Delta \Delta C T}$ and presented as a percentage relative to control samples. Quantification of mRNA expression was conducted, using iQ SYBR Green Supermix (Bio-Rad Laboratories), and thermocycling was followed as described elsewhere ${ }^{86}$. The sequences of primers used were as follows: human ALDH1A1 (5'-AGGGGCAGCCATTTCTTCTCA-3' and 5'-GCCCCTTCTTTCTTCCCACTCT-3'), mouse ALDH1A1 (5'GGGCAGCCATCTCCTCTCACAT-3' and 5'-GTTCCCCCAGCGTCCTCCAC-3'), human GAPDH (5'-GCGGGGCTCTCCAGAACATCAT-3' 
CCAGCCCCAGCGTCAAAGGTG-3'),

mouse

GAPDH

$\left(5^{\prime}-\right.$

CGGCAAATTCAACGGCACAGTCAA-3' and 5'-CTTTCCAGAGGGGCCATCCACAG-3').

\subsection{ALDH activity assay}

ALDH activity was detected with spectrophotometric assay by measuring NADH production ${ }^{83}$. Briefly, mouse liver lysate or cell lysate were mixed with sodium pyrophosphate buffer $(50 \mathrm{mM}, \mathrm{pH} 7.4), \mathrm{NAD}^{+}(5 \mu \mathrm{M})$, and rotenone $(4 \mu \mathrm{M})$. Propanal $(10 \mu \mathrm{M})$ was then added to initiate the reaction. The assay was allowed to run for 30 minutes at room temperature, and the end-point absorbance was determined at $340 \mathrm{~nm}$. ALDH activity was expressed as $\mu$ mole NADH/ $\mu \mathrm{g}$ protein/minute.

\subsection{Cell adhesion assay}

To assess CSC adhesion, the cells were incubated with NaHS for 24 hours. Afterwards, the cells were collected and re-seeded onto new plates with equal cell number $(20,000)$. After two hours, the cells were washed and fixed using $4 \%$ paraformaldehyde for 15 minutes followed by staining with Hoechst $33258(1 \mu \mathrm{g} / \mathrm{mL})$ for 30 minutes. The cell adhesion was observed under a fluorescence microscope (Olympus IX71) and counted using Image J software ${ }^{87}$.

\subsection{Statistical Analysis}

Data was expressed as mean \pm standard error of at least 3 separate experiments. Statistical analysis was conducted using student's T-Test. Values of $\mathrm{p}<0.05$ were considered statistically significant. 


\section{Results}

\subsection{DSF reacts with thiol-containing compounds under physiological conditions}

Given that DSF contains four sulphur atoms, the potential for DSF to yield $\mathrm{H}_{2} \mathrm{~S}$ under a variety of physiologically relevant conditions was assessed. At physiological $\mathrm{pH}$ and temperature, DSF did not spontaneously react to yield $\mathrm{H}_{2} \mathrm{~S}$ (Fig. 5A). We next assessed the ability of DSF to react with common additives. $\mathrm{Cu}^{2+}$ is often used to enhance the cytotoxic effects of DSF, as it stabilizes DSF's reduced form, diethyldithiocarbamate (DDC) ${ }^{46}$. The presence of $\mathrm{Cu}^{2+} \mathrm{did}$ not react with DSF to produce $\mathrm{H}_{2} \mathrm{~S}$ (Fig. $\mathbf{5 B}$ ). We then sought to determine the effects of various oxidizing/redox compounds on $\mathrm{H}_{2} \mathrm{~S}$ release from DSF. Hydrogen peroxide $\left(\mathrm{H}_{2} \mathrm{O}_{2}\right)$ had no effect on $\mathrm{H}_{2} \mathrm{~S}$ release from DSF (Fig. 5 C). This is not surprising, as both compounds are oxidizing agents. In contrast, it was observed that DSF reacted with reduced glutathione (GSH) to produce $\mathrm{H}_{2} \mathrm{~S}$, but DSF failed to react with the oxidized GSSG for generating $\mathrm{H}_{2} \mathrm{~S}$ (Fig. $\mathbf{5} \boldsymbol{D}$ and $\mathbf{5} \boldsymbol{E}$ ). The release of $\mathrm{H}_{2} \mathrm{~S}$ from the DSF-GSH reaction indicates that thiol-based reducing agents are able to react with DSF and release $\mathrm{H}_{2} \mathrm{~S}$. This was further confirmed when DSF successfully liberated $\mathrm{H}_{2} \mathrm{~S}$ from dithiothreitol (DTT) and 2-mercaptoethanol (2-Mer) (Fig. 5F and $\mathbf{5 G}$ ). In addition, ascorbic acid did not react with DSF to release $\mathrm{H}_{2} \mathrm{~S}$, suggesting that the sulphur atom liberated in the previous reactions was derived from the thiol-containing reducing agents but not DSF (Fig. $\mathbf{5 H}$ ). However, when DSF was mixed with common $\mathrm{H}_{2} \mathrm{~S}$-releasing donors ( $\mathrm{NaHS}$ or $\mathrm{Na}_{2} \mathrm{~S}_{3}$ ), DSF reduced $\mathrm{H}_{2} \mathrm{~S}$ release in a dose-dependent manner, suggesting that DSF may also act as an $\mathrm{H}_{2} \mathrm{~S}$ scavenger (Fig. $\mathbf{5 I}$ and $\mathbf{5} \boldsymbol{J})$. 


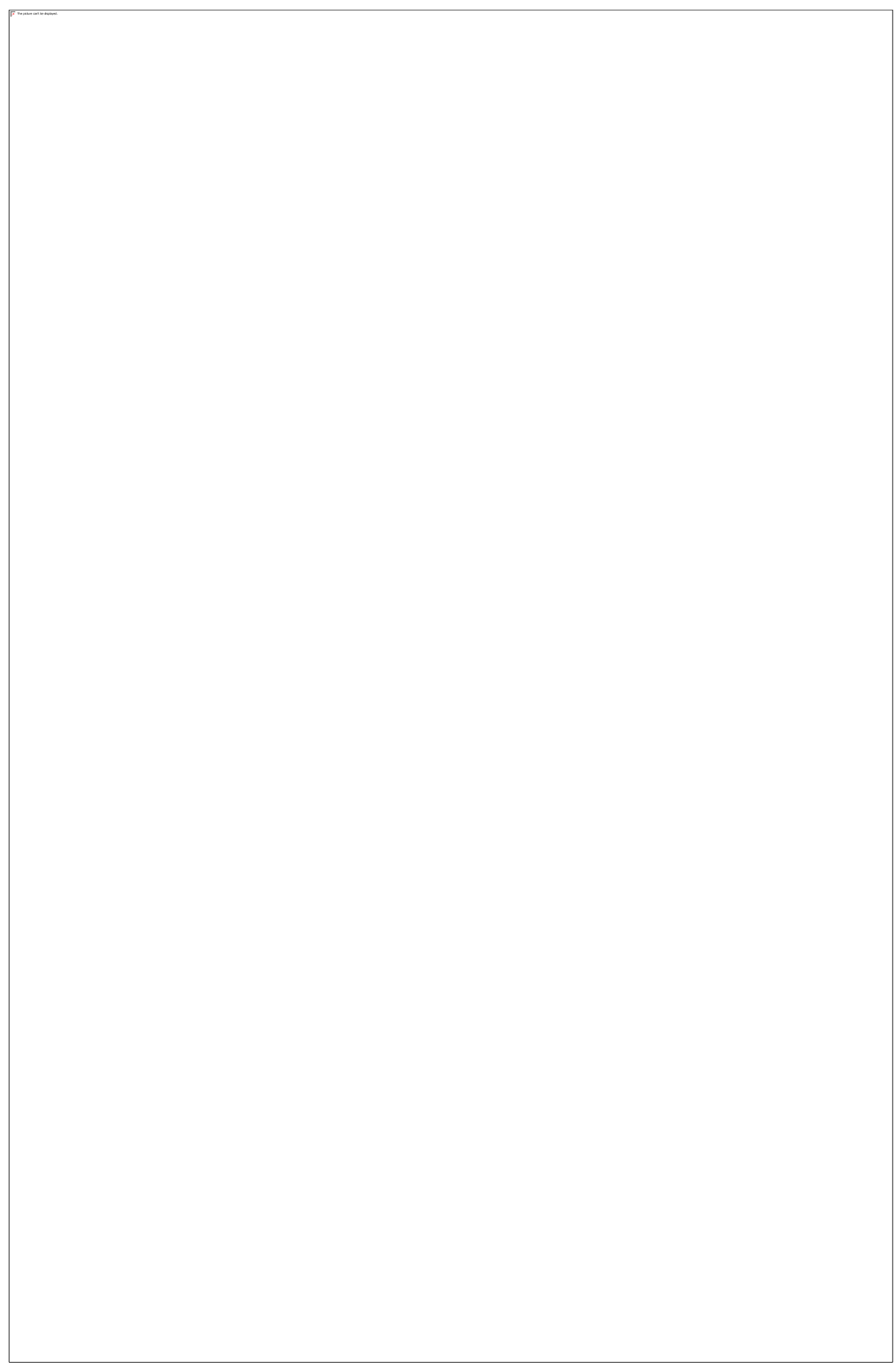

Figure 5 DSF reacts with thiol-containing compounds under physiological conditions. Different concentration of DSF $(0-100 \mu \mathrm{M}, \boldsymbol{A})$ were mixed with $\mathrm{CuCl}_{2}(1 \mu \mathrm{M}, \boldsymbol{B}), \mathrm{H}_{2} \mathrm{O}_{2}(100 \mu \mathrm{M}$, $\boldsymbol{C})$, GSH (1 mM, D), GSSG (1 mM, E), DTT (100 $\mu, \boldsymbol{F}), 2-\operatorname{Mer}(100 \mu \mathrm{M}, \boldsymbol{G})$, ascorbic acid $(100 \mu \mathrm{M}$, 
$\boldsymbol{H})$, NaHS $(100 \mu \mathrm{M}, \boldsymbol{I})$, or $\mathrm{Na}_{2} \mathrm{~S}_{3}(100 \mu \mathrm{M}, \boldsymbol{J})$ for 2 hours at $37^{\circ} \mathrm{C} . \mathrm{H}_{2} \mathrm{~S}$ release was trapped by lead acetate paper and intensity was determined using image $\mathrm{J}$ software. ${ }^{*}, p<0.05$ vs. control, $\mathrm{n}=3$.

To gain a more comprehensive understanding of DSF's reactions with thiols for $\mathrm{H}_{2} \mathrm{~S}$ release, we then tested the effects of $\mathrm{Cu}^{2+}, \mathrm{pH}$ and temperature on the DSF-GSH reaction. Addition of $\mathrm{Cu}^{2+}$ to this reaction caused a slight, though statistically insignificant change in $\mathrm{H}_{2} \mathrm{~S}$ release (Fig. 6A). Temperature changes from $37^{\circ} \mathrm{C}$ to $22^{\circ} \mathrm{C}$ had no substantial change in $\mathrm{H}_{2} \mathrm{~S}$ release (Fig. $\mathbf{6 B})$. The change of $\mathrm{pH}$ from neutral (pH 7.0) to basic (pH 10.0) also showed no effect (Fig. $6 \boldsymbol{C}$ ). Acidic condition ( $\mathrm{pH}$ 4.0), however, prevented the reaction from occurring, suggesting deprotonation of GSH is required for DSF-catalyzed $\mathrm{H}_{2} \mathrm{~S}$ release. 


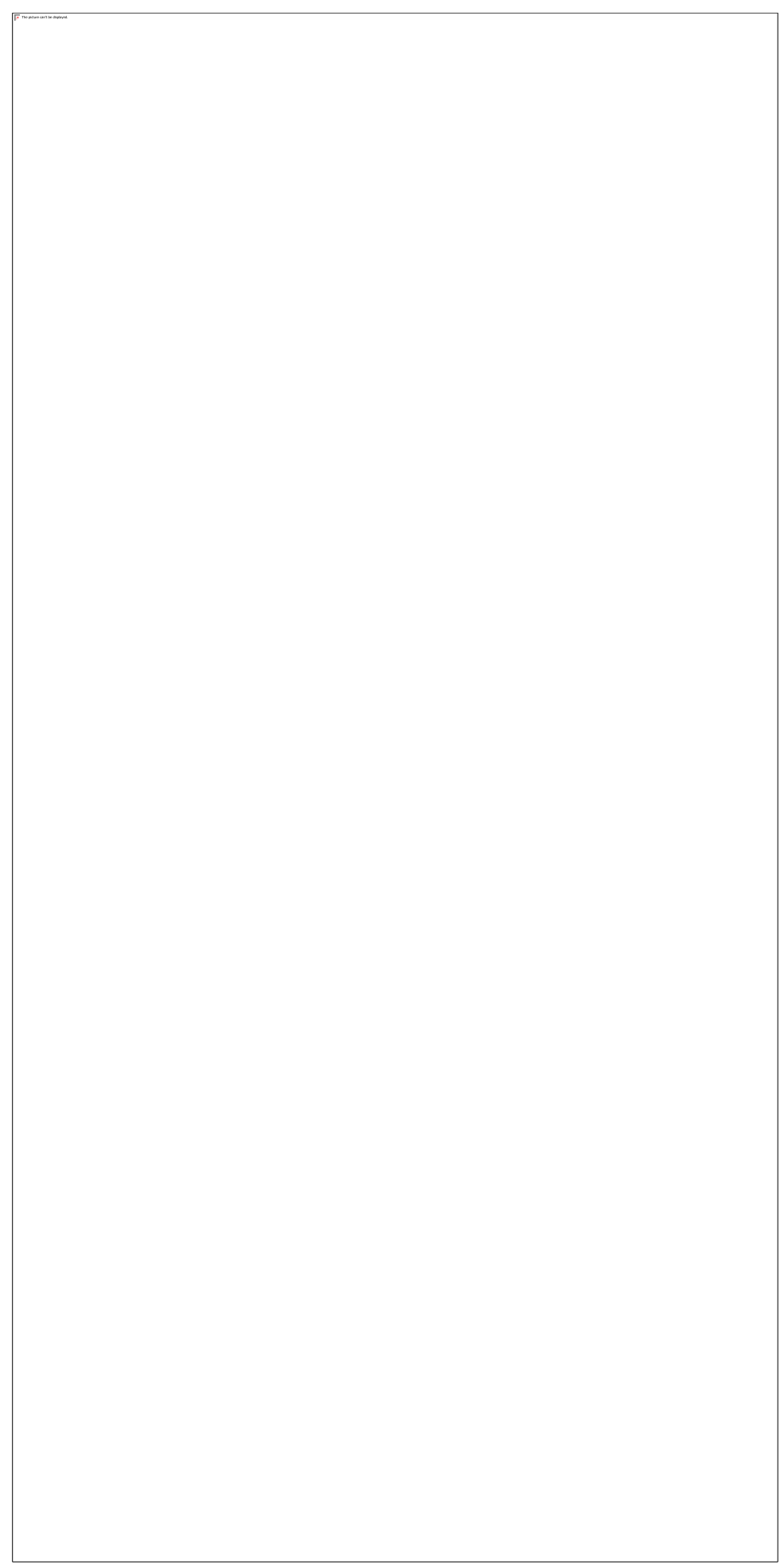

Figure 6 The effects of $\mathrm{Cu}^{2+}$, pH and temperature on $\mathrm{H}_{2} \mathrm{~S}$ release from DSF-GSH interaction. $\operatorname{DSF}(10 \mu \mathrm{M})$ was mixed with $\mathrm{GSH}(1 \mathrm{mM})$ in the presence of $\mathrm{CuCl}_{2}(1 \mu \mathrm{M}, \boldsymbol{A})$, or incubated at room 
temperature $(\boldsymbol{B})$, or under various $\mathrm{pH}$ conditions $(\boldsymbol{C}) . \mathrm{H}_{2} \mathrm{~S}$ release was trapped by lead acetate paper and intensity was determined using image $\mathrm{J}$ software. *, $p<0.05$ vs. control, $\mathrm{n}=3$.

\subsection{DSF stimulates $\mathrm{H}_{2} \mathrm{~S}$ release in mouse liver tissues}

Liver is the single largest contributor to $\mathrm{H}_{2} \mathrm{~S}$ generation in our body ${ }^{62,82}$. By incubating mouse liver lysate for 2 hours in the presence of cysteine and P5P, we found that DSF could significantly increase $\mathrm{H}_{2} \mathrm{~S}$ production in a dose-dependent manner (Fig. 7A). The further addition of $\mathrm{Cu}^{2+}$ facilitated DSF-induced $\mathrm{H}_{2} \mathrm{~S}$ release in liver lysate, indicating that the stabilization of DDC by $\mathrm{Cu}^{2+}$ may promote $\mathrm{H}_{2} \mathrm{~S}$ production (Fig. $7 \boldsymbol{B}$ ). $\mathrm{H}_{2} \mathrm{O}_{2}$ failed to alter $\mathrm{H}_{2} \mathrm{~S}$ output, while either $\mathrm{GSH}$ or GSSG completely ablated $\mathrm{H}_{2} \mathrm{~S}$ production (Fig. $7 \boldsymbol{B}$ ), pointing to the possible reaction of GSH/GSSG with DSF leading to inactivation of DSF in stimulating $\mathrm{H}_{2} \mathrm{~S}$ release from liver lysate. It was further demonstrated that simply mixing different concentration of DSF with cysteine but not $\mathrm{P} 5 \mathrm{P}$ induced $\mathrm{H}_{2} \mathrm{~S}$ release in the absence of liver tissues, validating that DSF can interact with certain thiol-containing compounds for $\mathrm{H}_{2} \mathrm{~S}$ release, and that DSF induces enzymatic release of $\mathrm{H}_{2} \mathrm{~S}$ (Fig. $7 C$ and 7D). 


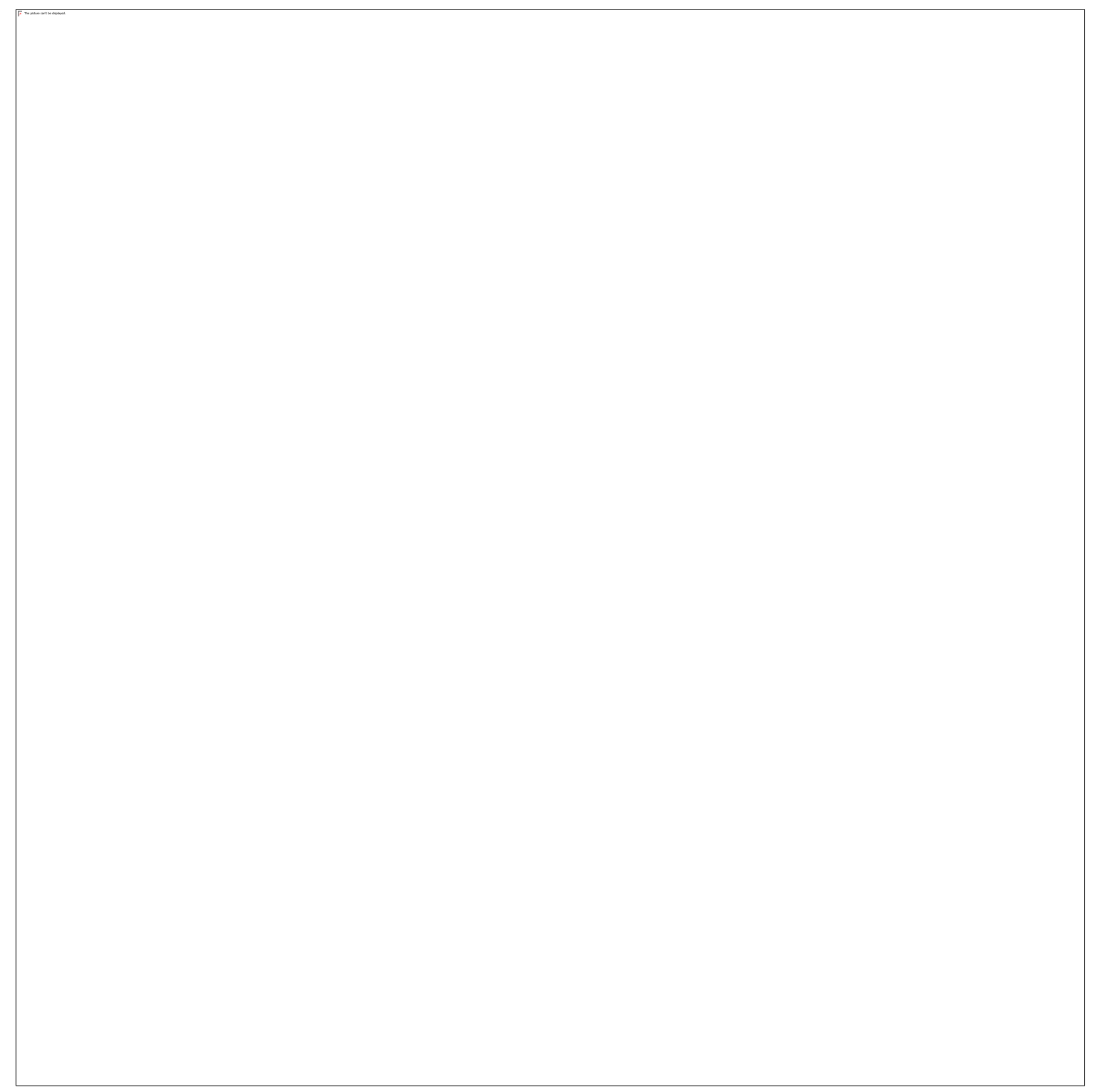

Figure 7 DSF stimulated $\mathrm{H}_{2} \mathrm{~S}$ production in WT mouse liver lysate. $\boldsymbol{A}$, DSF $(0-100 \mu \mathrm{M})$ was mixed with WT mouse liver lysate $(5 \mathrm{mg})$ in the presence of cysteine $(5 \mathrm{mM})$ and P5P $(1 \mathrm{mM}) . \boldsymbol{B}$, DSF $(0-100 \mu \mathrm{M})$ was mixed with WT mouse liver lysate in the presence of cysteine and P5P with additional agents, including $\mathrm{CuCl}_{2}(1 \mu \mathrm{M}), \mathrm{H}_{2} \mathrm{O}_{2}(100 \mu \mathrm{M})$, GSH $(1 \mathrm{mM})$, or GSSG $(1 \mathrm{mM}) . \boldsymbol{C}$ and $\boldsymbol{D}$, DSF $(0-100 \mu \mathrm{M})$ was mixed with cysteine $(5 \mathrm{mM})$ or P5P $(1 \mathrm{mM})$ only. The mixtures were incubated for 2 hours at $37^{\circ} \mathrm{C} . \mathrm{H}_{2} \mathrm{~S}$ release was trapped by lead acetate paper and intensity was determined using image $\mathrm{J}$ software. *, $\mathrm{p}<0.05$ vs. control, $\mathrm{n}=3$. 
The increase in $\mathrm{H}_{2} \mathrm{~S}$ production from mouse liver lysates by DSF would suggest that either DSF is metabolized to produce $\mathrm{H}_{2} \mathrm{~S}$, or that DSF itself or its metabolite(s) activates the $\mathrm{H}_{2} \mathrm{~S}$ generating enzyme, CSE. It was validated here that $\mathrm{H}_{2} \mathrm{~S}$ release was hardly observed in liver tissues from CSE knockout (CSE-KO) mice (Fig. 8A). Unlike the dose-dependent stimulation of $\mathrm{H}_{2} \mathrm{~S}$ release in the liver tissues from wild-type (WT) mice, DSF showed no effect on $\mathrm{H}_{2} \mathrm{~S}$ release in CSE-KO mouse liver lysates (Fig. 8A). These data indicate that DSF may target CSE to promote $\mathrm{H}_{2} \mathrm{~S}$ release. We next examined the effects of DSF on CSE expression in HepG2 cells. As shown in Fig. 8B , incubation of HepG2 cells with $10 \mu \mathrm{M}$ DSF for 24 hours increased CSE protein expression by more than 2 times. In combination, this evidence shows DSF is able to stimulate $\mathrm{H}_{2} \mathrm{~S}$ production by upregulating CSE protein expression and also directly inducing CSE activity. 


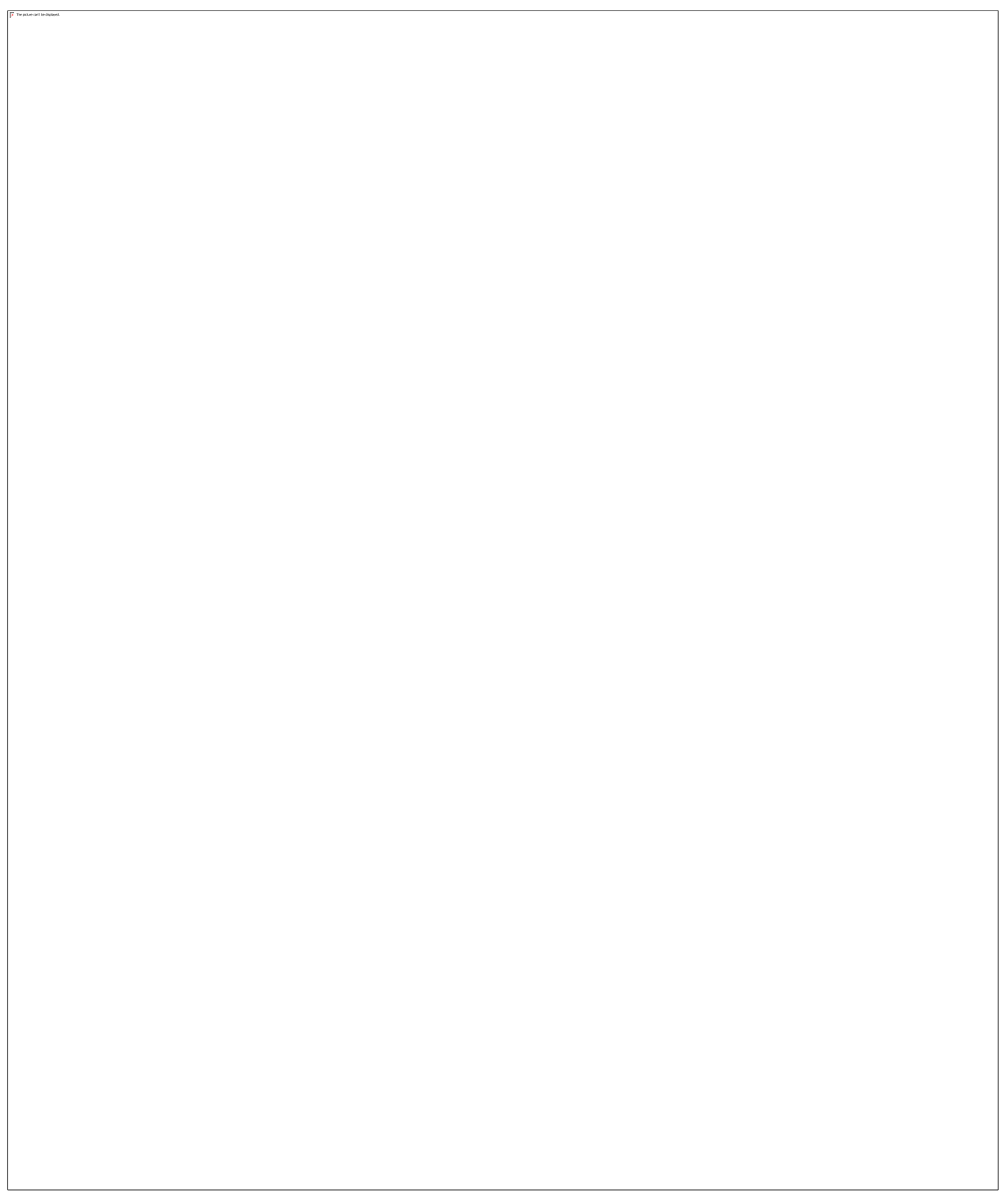

Figure 8 DSF targets at CSE for $\mathrm{H}_{2}$ S production. $\boldsymbol{A}$, DSF (10-100 $\left.\mu \mathrm{M}\right)$ was mixed with WT or CSE-KO mouse liver lysate $(5 \mathrm{mg})$ in the presence of cysteine $(5 \mathrm{mM})$ and P5P $(1 \mathrm{mM})$. The mixtures were incubated for 2 hours at $37^{\circ} \mathrm{C} . \mathrm{H}_{2} \mathrm{~S}$ release was trapped by lead acetate paper and intensity was determined using image $\mathrm{J}$ software. *, $\mathrm{p}<0.05$ vs. WT control, $\mathrm{n}=3$. $\boldsymbol{B}$, HepG2 cells were incubated with DSF $(10 \mu \mathrm{M})$ for 24 hours, and CSE expression was determined using western blotting. *, $p<$ 0.05. $\mathrm{n}=3$. 


\section{3 $\quad \mathrm{H}_{2} \mathrm{~S}$ inhibits ALDH expression and activity}

Previous work showed that $\mathrm{H}_{2} \mathrm{~S}$ may act a novel inhibitor of ALDH activity ${ }^{20}$. We expanded upon this finding and examined the effects of $\mathrm{H}_{2} \mathrm{~S}$ on both ALDH activity and expression. Treatment with either $\mathrm{H}_{2} \mathrm{~S}$ or DSF inhibited ALDH protein expression and mRNA levels in HepG2 cells, while combined treatment with both conferred no additional inhibition (Fig. $\mathbf{9 A}$ and $\mathbf{9 B}$ ). We also examined the direct effect of $\mathrm{H}_{2} \mathrm{~S}$ on ALDH activity. HepG2 lysates mixed with either DSF or $\mathrm{H}_{2} \mathrm{~S}$ showed lower ALDH enzymatic activity, while combined treatment of $\mathrm{H}_{2} \mathrm{~S}$ and DSF had a cumulative effect in inhibiting ALDH activity (Fig. 9C). The role of endogenous $\mathrm{H}_{2} \mathrm{~S}$ in ALDH regulation was further determined by assessing ALDH expression and activity in CSE-KO mouse liver tissue. In comparison with WT liver tissues, the mRNA and protein expressions as well as the activity of ALDH were all significantly higher in CSE deficient tissue (Fig. 10A-C). These data indicate that $\mathrm{H}_{2} \mathrm{~S}$ inhibits ALDH in a DSF-like manner by reducing mRNA and protein expressions and also decreasing enzymatic activity. 


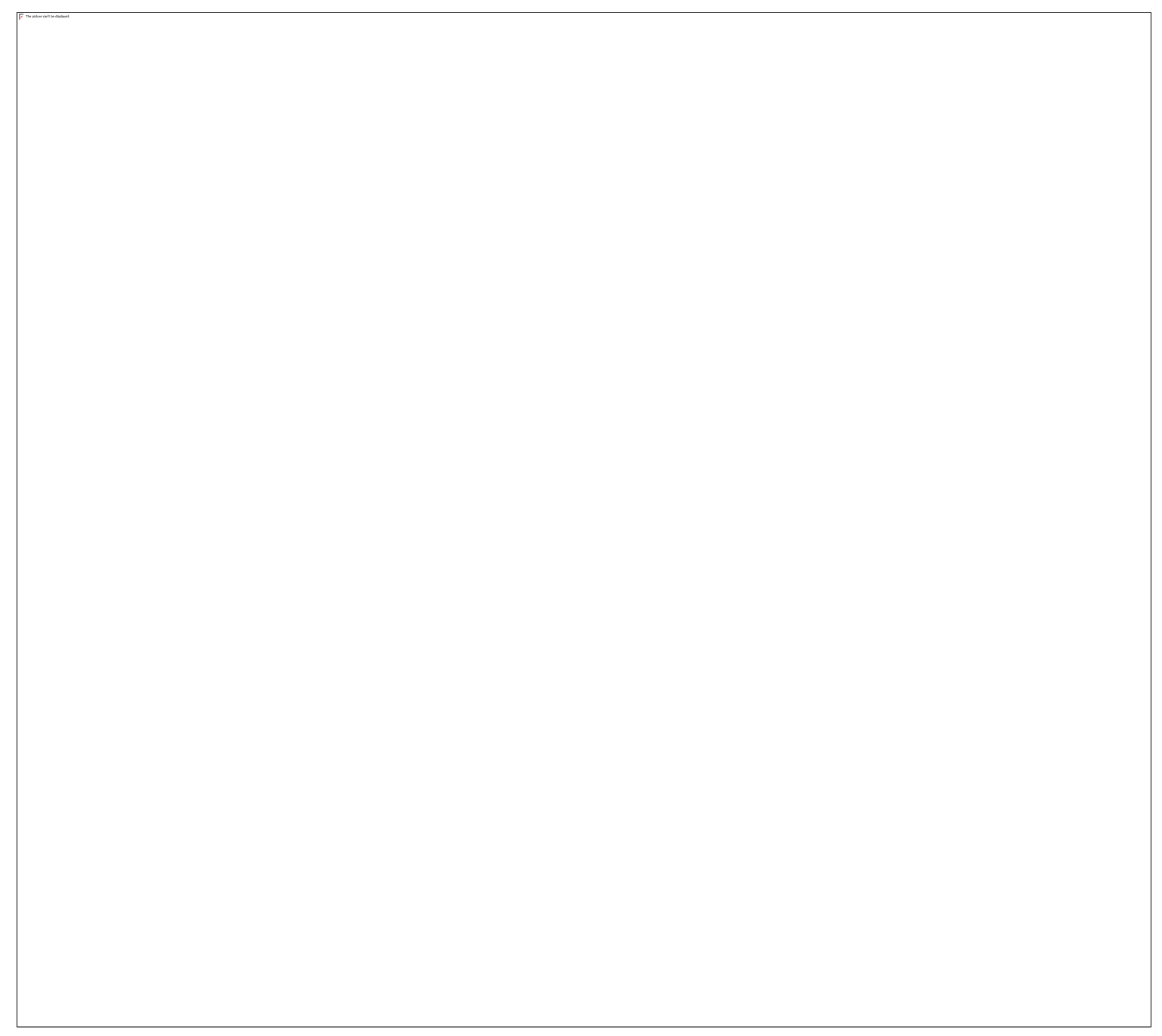

Figure 9 DSF and $\mathrm{H}_{2} \mathrm{~S}$ inhibit the expression and activity of ALDH. HepG2 cells were incubated with $\mathrm{H}_{2} \mathrm{~S}(30 \mu \mathrm{M})$, DSF $(10 \mu \mathrm{M})$, or both for 24 hours. $\mathrm{H}_{2} \mathrm{~S}$ was added 30 minutes prior to DSF. The cells were then collected for analysis of ALDH protein expression $(\boldsymbol{A})$, mRNA expression $(\boldsymbol{B})$, and activity $(\boldsymbol{C}) .{ }^{*}, p<0.05$ vs. control, $\mathrm{n}=3$. 


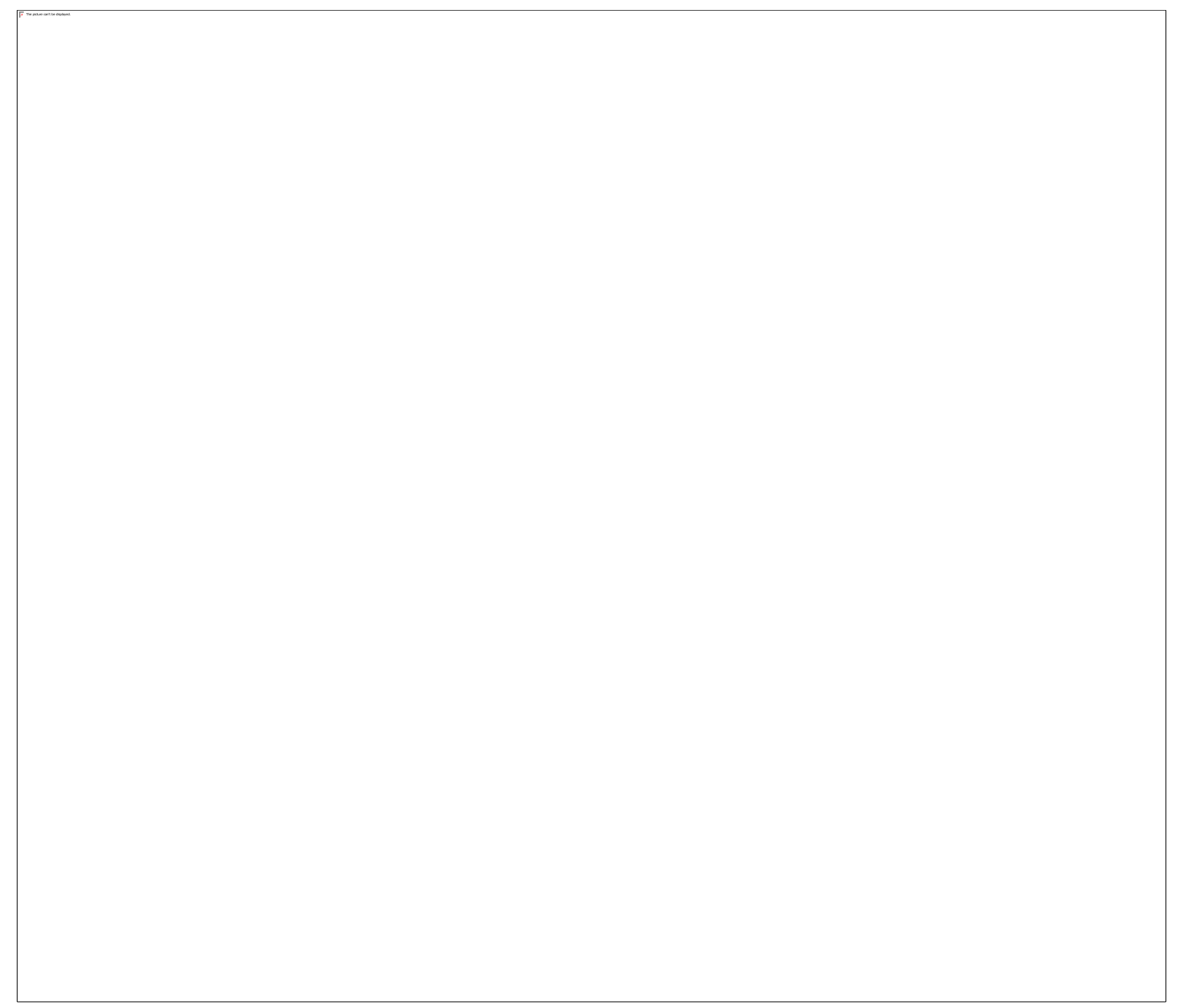

Figure 10 Deficiency of CSE promotes the expression and activity of ALDH. Both WT and CSE-KO mouse liver tissues were used for analysis of ALDH protein expression $(\boldsymbol{A})$, mRNA expression $(\boldsymbol{B})$, and activity $(\boldsymbol{C}){ }^{*}, p<0.05$ vs. control, $\mathrm{n}=3$. 


\section{4 $\mathrm{H}_{2} \mathrm{~S}$ sensitizes DSF-inhibited cell viability and inhibits CSC adhesion}

Incubation of $\mathrm{HepG} 2$ cells with either $\mathrm{H}_{2} \mathrm{~S}$ or DSF alone had no effect on cell growth, as demonstrated by the cell viability test and cell number counting (Fig. 11A and 11B). However, when added together, $\mathrm{H}_{2} \mathrm{~S}$ was shown to significantly sensitize DSF-inhibited cell growth. The CSE expression and endogenous $\mathrm{H}_{2} \mathrm{~S}$ generation between mouse liver cancer stem cells (Dt81 Hepa1-6 or 81S) and their parental cells (Hepa1-6 or 16) were then compared ${ }^{24}$. Compared to the parental 16cell line, CSE levels in the 81S cells were dramatically abolished (Fig. 11C). $\mathrm{H}_{2} \mathrm{~S}$ generation in $81 \mathrm{~S}$ cells were only $38 \%$ of that in 16 cells (Fig. 11D). As expected, we also observed a higher ALDH protein expression in $81 \mathrm{~S}$ cells than 16 cells (Fig 11E). Incubation of both $81 \mathrm{~S}$ and 16 cells with $\mathrm{H}_{2} \mathrm{~S}$ lead to significant lower expression of ALDH. The effect of $\mathrm{H}_{2} \mathrm{~S}$ on CSE functions was further tested. The $81 \mathrm{~S}$ cells showed more cell adhesion in comparison with 16 cells, while the supplement of $\mathrm{H}_{2} \mathrm{~S}$ treatment was able to reduce the increased cell adhesion in 81s cells (Fig. 11F ). We did not observe any effect of $\mathrm{H}_{2} \mathrm{~S}$ on 16 cell adhesion. These data indicate that $\mathrm{H}_{2} \mathrm{~S}$ may inhibit mouse CSC functions by possibly targeting ALDH. 


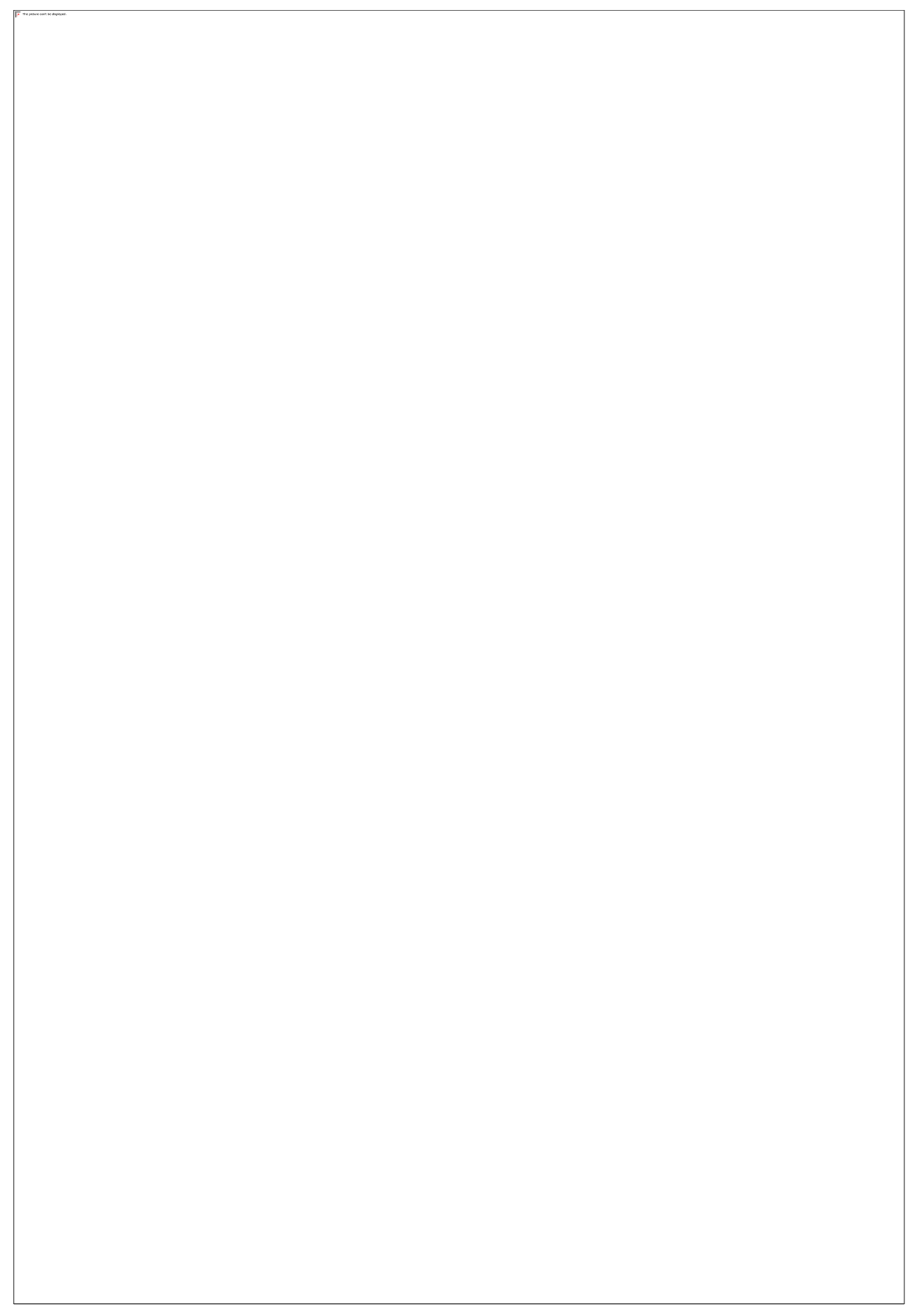

Figure $11 \quad \mathrm{H}_{2} \mathrm{~S}$ sensitizes DSF-inhibited cell viability and inhibits CSC adhesion. HepG2 cells incubated with $\mathrm{H}_{2} \mathrm{~S}(30 \mu \mathrm{M})$, DSF $(10 \mu \mathrm{M})$, or both for 24 hours were tested for cell viability by MTT $(\boldsymbol{A})$ and cell number counting $(\boldsymbol{B}) .{ }^{*}, p<0.05$ vs. control. Both 16 and $81 \mathrm{~S}$ cells grown to confluence were collected and tested for CSE expression by western blotting $(\boldsymbol{C})$ and endogenous $\mathrm{H}_{2} \mathrm{~S}$ production using lead acetate paper method $(\boldsymbol{D}) .^{*}, p<0.05$ vs. 16 cells. Both 16 and $81 \mathrm{~S}$ cells 
were incubated with or without $\mathrm{H}_{2} \mathrm{~S}(30 \mu \mathrm{M})$ for 24 hours, the cells were collected for analysis of ALDH protein expression $(\boldsymbol{E}){ }^{*}, p<0.05$ vs. 16 control cells; \#, $\mathrm{p}<0.05$ vs. $81 \mathrm{~S}$ control cells. $\mathrm{n}=3$. After incubation with or without $\mathrm{H}_{2} \mathrm{~S}$ for 24 hours, both 16 and $81 \mathrm{~S}$ cells were collected and replated for additional 2 hours, then stained using Hoechst 33258 for analysis of cell adhesion $(\boldsymbol{F})$. $*, p<0.05$ vs. all groups. $\mathrm{n}=3$. 


\section{Discussion}

Tumours are complex systems comprised of heterogeneous cells, and by selectively eliminating those with the greatest capacity for proliferation, replication, and treatment resistance, the threat of the tumour as a whole can be practically nullified ${ }^{88}$. As such, developing novel methods to selectively target CSCs and prevent disease progression is of vital interest ${ }^{89}$. By targeting ALDH, inhibitors such as DSF are able to selectively induce cell death in treatment resistant cells, without placing significant toxic burden on healthy cells ${ }^{19}$. The regulatory role of $\mathrm{H}_{2} \mathrm{~S}$ on ALDH provides a greater understanding of the development of drug-resistant cancers, and increases the scope of potential CSC treatments. The present study highlights the inhibitory effects of both endogenous and exogenous $\mathrm{H}_{2} \mathrm{~S}$ on $\mathrm{ALDH}$ expression, ALDH activity, and cancer viability.

Despite the growing number of studies on the biomedical effects of $\mathrm{H}_{2} \mathrm{~S}$, adequate strategies for maintaining the proper level of endogenous $\mathrm{H}_{2} \mathrm{~S}$ are very limited. $\mathrm{H}_{2} \mathrm{~S}$ generation can be disabled or over-activated under different stress conditions ${ }^{81,90}$. Therefore, finding new compounds or systems to buffer $\mathrm{H}_{2} \mathrm{~S}$ generation for bench research and potential therapeutic applications are urgently needed. Here we determined that DSF acts as a potent $\mathrm{H}_{2} \mathrm{~S}$-releasing donor. In the presence of thiol antioxidants, including GSH, DTT, 2-Mer, or cysteine, a significant $\mathrm{H}_{2} \mathrm{~S}$ release was observed from DSF. GSH has been shown to promote the desulfuration of DDTCMe and DDTC-Me sulfine, two metabolites of DSF ${ }^{91}$. Further evidence suggest that GSH would attack the oxithiirane isomer of DDTC-Me sulfine, resulting in its structural change followed by generation of GSSG and $\mathrm{H}_{2} \mathrm{~S}^{91}$. Interestedly, DSF itself has also been shown to induce both GSH and GSSG level, which is attributed to the mutual interconversion of DSF with its metabolite ${ }^{92}$. 
The other thiol compounds may act in a similar way as GSH to react with DSF for generating $\mathrm{H}_{2} \mathrm{~S}$. It should be noted here, at physiological condition, all these compounds would not spontaneously release $\mathrm{H}_{2} \mathrm{~S}$. DSF's therapeutic potential has often been enhanced by in conjunction with copper, however we did not observe any effect of $\mathrm{Cu}^{2+}$ on $\mathrm{H}_{2} \mathrm{~S}$ release from DSF, indicating that copper interaction with DSF metabolites would block its desulfuration ${ }^{93}$. In addition, neither the oxidant $\mathrm{H}_{2} \mathrm{O}_{2}$ nor the antioxidant ascorbate liberates $\mathrm{H}_{2} \mathrm{~S}$ from DSF, pointing to the key role of thiol-thiol inter-attack for $\mathrm{H}_{2} \mathrm{~S}$ release. Unexpectedly, when directly mixing DSF and $\mathrm{H}_{2} \mathrm{~S}$ donors (NaHS or $\mathrm{Na}_{2} \mathrm{~S}_{3}$ ), we did not observe a synergetic increase, rather a substantial decrease of $\mathrm{H}_{2} \mathrm{~S}$ release. It is inferred that $\mathrm{H}_{2} \mathrm{~S}$ derived from NaHS or $\mathrm{Na}_{2} \mathrm{~S}_{3}$ can be quickly utilized for targeting at sulphur groups in DSF to facilitate an unknown chemical reaction. Given all this evidence, DSF can be a great candidate as a buffer system for maintaining endogenous $\mathrm{H}_{2} \mathrm{~S}$ levels. On one side, DSF can potentially liberate $\mathrm{H}_{2} \mathrm{~S}$ from very common intracellular thiol-containing compounds when endogenous $\mathrm{H}_{2} \mathrm{~S}$ is low; while on the other side, DSF can scavenge $\mathrm{H}_{2} \mathrm{~S}$ when endogenous $\mathrm{H}_{2} \mathrm{~S}$ generation is excessive. Therefore, we suggest that DSF may be an effective buffer for maintaining a therapeutically relevant $\mathrm{H}_{2} \mathrm{~S}$ level.

Moreover, when incubated with WT mouse liver lysates or human liver cancer cells, DSF was able to increase $\mathrm{H}_{2} \mathrm{~S}$ generation. CSE is recognized as a major source of $\mathrm{H}_{2} \mathrm{~S}$ in liver tissues ${ }^{62}$. In the absence of CSE, $\mathrm{H}_{2} \mathrm{~S}$ generation was not affected by the addition of DSF, pointing to the direct involvement of CSE in DSF-stimulated $\mathrm{H}_{2} \mathrm{~S}$ generation. It is possible that DSF may target the cysteine residues in CSE for altering its conformation and activity. In contrast, Zuhra et al. showed that DSF via its metabolite DDC-Cu inhibited CBS activity and $\mathrm{H}_{2} \mathrm{~S}$ levels in colon cancer cells ${ }^{94}$. The inconsistency may be due to the differences in cell types and/or the substrate/cofactors 
used. Not only involved in directly stimulating CSE activity, DSF was also shown to enhance CSE protein level. The duality of DSF on $\mathrm{H}_{2} \mathrm{~S}$ production positions it as a unique tool in regulating $\mathrm{H}_{2} \mathrm{~S}$. The surge in $\mathrm{H}_{2} \mathrm{~S}$ production provides immediate relief, while the overexpression of CSE sustains elevated $\mathrm{H}_{2} \mathrm{~S}$ for a longer duration. The complications involved in $\mathrm{H}_{2} \mathrm{~S}$ application are overcome with DSF within the liver, as the elevated CSE expression maintains therapeutic levels, a major concern with traditional donors such as NaHS ${ }^{95,96}$. The efficacy of DSF-induced $\mathrm{H}_{2} \mathrm{~S}$ release remains to be determined in vivo, which may determine DSF's practicality as an $\mathrm{H}_{2} \mathrm{~S}$ donor.

$\mathrm{ALDH}$ is an $\mathrm{NAD}(\mathrm{P})^{+}$-dependent enzyme responsible for catalyzing the conversion of aldehydes to carboxylic acids. By the covalent modification of active site cysteine residues in ALDH, DSF can cause the inactivation of ALDH ${ }^{58}$. The data presented herein further proved that ALDH activity was also inhibited by $\mathrm{H}_{2} \mathrm{~S}$. Two pathways would explain the inhibitory role of $\mathrm{H}_{2} \mathrm{~S}$ on ALDH activity. Similar to DSF, $\mathrm{H}_{2} \mathrm{~S}$ is known to generate most of its cellular functions by the $S$-sulfhydration of cysteine in target proteins. So, it is possible that $\mathrm{H}_{2} \mathrm{~S}$ directly targets the active cysteine residue in ALDH for suppressing its catalytic activity. In addition, $\mathrm{H}_{2} \mathrm{~S}$ may $S$-sulfhydrate some transcription factors for inducing ALDH transcription, as ALDH protein and mRNA expression were lower after $\mathrm{H}_{2} \mathrm{~S}$ treatment. It should be noted that the present study examined the expression of the ALDH1A1 isozyme in both protein and mRNA, but the measurement of ALDH activity was non-specific, suggesting that other ALDH isozymes may have contributed to this function.

Over the past few decades, ALDH has become recognized as a CSC marker ${ }^{97,98}$. ALDH upregulation increases the oxidative burden that cancer cells can tolerate and activates cell self- 
renewal. Inhibition of ALDH could attenuate CSC self-renewal, reduce tumorigenicity, and suppress chemo- and radio-therapy resistance, thus blocking cancer progression and metastasis 99,100. Consistently, our data here also revealed higher expression of ALDH in mouse liver CSCs (Dt81 Hepa1-6) ${ }^{84,101}$. In contrast, the expression of CSE and endogenous generation of $\mathrm{H}_{2} \mathrm{~S}$ were significantly lower in the CSCs in comparison with their parental cells (Hepa1-6). By inhibiting ALDH expression, $\mathrm{H}_{2} \mathrm{~S}$ was also able to suppress CSC function, as evidenced by lower cell adhesion. We previously reported that CSE expression was reduced in drug resistant liver cancer cells and supply of exogenous $\mathrm{H}_{2} \mathrm{~S}$ could reverse drug resistance in these cells ${ }^{81}$. Other studies also found that overexpression of CSE in T cells significantly inhibited tumour growth in a mouse model of adoptive cell transfer, while silencing CSE gene transcription via FOXC1-mediated DNMT3B expression and DNA hyper-methylation promoted hepatocellular carcinoma survival 102,103. This evidence demonstrated a key role of $\mathrm{CSE} / \mathrm{H}_{2} \mathrm{~S}$ system in regulating cancer growth and drug resistance possibly by targeting at ALDH. DSF exerts a synergetic therapeutic effect on cancer when administered in combination with other chemotherapeutic drugs, such as cisplatin, 5fluorouracil, temozolomide, etc ${ }^{33,104,105}$. Here it was further showed that combination of both DSF and $\mathrm{H}_{2} \mathrm{~S}$ displayed significantly inhibitory role on liver cancer cell growth. It cannot be excluded that the anti-cancer effects of DFS and $\mathrm{H}_{2} \mathrm{~S}$ may be due to a result of multiple mechanisms that act synergistically.

$\mathrm{H}_{2} \mathrm{~S}$ deficiency increases susceptibility to many diseases, including disorders such as liver cirrhosis and atherosclerosis ${ }^{65,67}$. We present evidence for CSE-deficiency as a hallmark of cancer development, and potentially as a CSC marker. The increase in ALDH expression seen in CSEKO liver tissue would suggest that altered CSE expression or function may be a major contributor 
to the development of cancer. CSE-deficiency as a marker for cancer progression is further supported by the absence of CSE and $\mathrm{H}_{2} \mathrm{~S}$ production in the Dt81 Hepa1-6 CSC model. In developing their CSC model, Lacoste et al. used intrasplenic passage of Hepa1-6 cells in vivo, and isolated cells from the largest resultant tumour ${ }^{84}$. CSE-deficiency in these cells therefore imparts some advantages to the cancer cells in regards to increased proliferative activity. $\mathrm{H}_{2} \mathrm{~S}$ deficiency has shown to increase proliferation and drug resistance in both cancerous and non-cancerous cells, such as glioblastoma and smooth muscles cells ${ }^{106,107}$. A likely mechanism for these observations is the increase in ALDH expression in CSE deficient tissues, as evidenced by the increase in ADLH seen in CSE-KO mouse liver. Elevated ALDH likely promotes Hedgehog through Gli2, increasing cell proliferation. Therefore, monitoring endogenous $\mathrm{H}_{2} \mathrm{~S}$ production could aid in determining the severity and risk of relapse or metastases.

The regulation of the cell cycle and the antioxidant response by $\mathrm{H}_{2} \mathrm{~S}$ often reduces the risk of developing myriad diseases, including cancer, while exogenous application often halts or reverses disease progression ${ }^{108-110}$. In certain cases, however, $\mathrm{H}_{2} \mathrm{~S}$ appears to promote or benefit cancer progression ${ }^{111-114}$. Inhibition of ALDH by $\mathrm{H}_{2} \mathrm{~S}$ may provide an explanation for the apparent duality of $\mathrm{H}_{2} \mathrm{~S}$ in cancer treatment. ALDH overexpression increases the oxidative burden that the cell can tolerate by rapidly metabolizing aldehydes before DNA and protein damage can occur ${ }^{19}$. By targeting ALDH, CSCs lose their ability to cope with the elevated oxidative stress which accumulates during chemotherapy, resulting in apoptosis. While effective in targeting CSCs, this would suggest that cancer cells under lower oxidative stress are less affected by $\mathrm{H}_{2} \mathrm{~S}$ alone, and in fact benefit from the activation of proliferative pathways. By combining $\mathrm{H}_{2} \mathrm{~S}$ with traditional 
chemotherapies, highly-tumorigenic CSCs are more susceptible to treatment, and the entire tumour population could be treated effectively.

While not explicitly observed in this study, the reduction in ALDH expression after $\mathrm{H}_{2} \mathrm{~S}$ treatment likely resulted in decreased activation of Hedgehog, owing to the loss of Gli2 stabilization ${ }^{23}$. Any future work into the $\mathrm{H}_{2} \mathrm{~S}$-mediated inhibition of ALDH should examine the effects of $\mathrm{H}_{2} \mathrm{~S}$ on Gli2. To best understand how $\mathrm{H}_{2} \mathrm{~S}$ can regulate Gli2/Hedgehog, the mechanism through which $\mathrm{H}_{2} \mathrm{~S}$ decreases ALDH protein and mRNA transcripts should be determined. While the inhibition of ALDH could result in the degradation of inactive protein, $\mathrm{H}_{2} \mathrm{~S}$ may act to directly reduce the transcription of ALDH by regulating some as-of-yet unknown transcription factor.

The demonstration that $\mathrm{H}_{2} \mathrm{~S}$ inhibits ALDH suggests that both DSF and $\mathrm{H}_{2} \mathrm{~S}$ share other molecular targets. As previously mentioned, $\mathrm{H}_{2} \mathrm{~S}$ regulates a wide range of intracellular processes by targeting proteins such as GAPDH or ATP channels ${ }^{62,75}$. This may suggest that DSF is capable of acting on some of the known targets for $S$-sulfhydration, assuming the larger molecule is able to access the binding site. If DSF is able to act on known $\mathrm{H}_{2} \mathrm{~S}$ targets, DSF could become a viable treatment for $\mathrm{H}_{2} \mathrm{~S}$ deficiency related disorders. Simultaneously, $\mathrm{H}_{2} \mathrm{~S}$ may also be able to react with some of DSF's alternate targets, which including enzymes such as phosphoglycerate dehydrogenase or the proteasome ${ }^{34,115}$. If true, this could result in a substantial improvement of our understanding of $\mathrm{H}_{2} \mathrm{~S}$-mediated regulation.

The findings presented in this thesis suggest two significant and novel contributions to our understanding of ALDH regulation. First, $\mathrm{H}_{2} \mathrm{~S}$ acts as an inhibitor of ALDH, with endogenous $\mathrm{H}_{2} \mathrm{~S}$ 
production regulating ALDH expression. This raises the potential for $\mathrm{H}_{2} \mathrm{~S}$ donors or treatments which enhance CSE activity as novel therapies for CSCs. The second finding is the role of $\mathrm{H}_{2} \mathrm{~S}$ in DSF's function. With prolonged incubation, DSF increases CSE expression, and in the short term directly increases $\mathrm{H}_{2} \mathrm{~S}$ release from liver lysate in a CSE-dependent mechanism. These effects combined increase total $\mathrm{H}_{2} \mathrm{~S}$ content, allowing DSF to influence cell signalling pathways. DSFinduced $\mathrm{H}_{2} \mathrm{~S}$ production then suggests that DSF may act to inhibit ALDH indirectly through $S$ sulfhydration, and in turn suggests the drug may impact the regulation of metabolism, cell cycle, and cell death.

\section{Conclusion}

This study reveals a novel role of DSF in promoting $\mathrm{H}_{2} \mathrm{~S}$ release from thiol-containing compounds. DSF is able to induce $\mathrm{H}_{2} \mathrm{~S}$ release in liver through CSE-dependent mechanisms, increasing CSE expression and long-term $\mathrm{H}_{2} \mathrm{~S}$ generation while simultaneously promoting CSE activity. $\mathrm{H}_{2} \mathrm{~S}$ treatment reduced ALDH expression and activity in a DSF-like manner, highlighting the role of $\mathrm{H}_{2} \mathrm{~S}$ in alcohol metabolism and as a potential CSC marker. Endogenous deficiency of $\mathrm{H}_{2} \mathrm{~S}$ in mouse liver results in increased ALDH expression, suggesting CSE-deficiency as a precursor to CSC development. Additionally, CSE expression and $\mathrm{H}_{2} \mathrm{~S}$ generation were lower in liver CSCs, which correspond with increased CSC function. Treatment with exogenous $\mathrm{H}_{2} \mathrm{~S}$ reduced CSC viability, suggesting that $\mathrm{H}_{2} \mathrm{~S}$ should be used as a novel CSC-targeting anti-cancer agent. DSF-induced CSE expression and $\mathrm{H}_{2} \mathrm{~S}$ production likely contributes directly to ALDH inhibition, cancer cell death, and CSC dysfunction (Fig. 12). In conclusion, the findings presented herein detail the inhibitory effects of $\mathrm{H}_{2} \mathrm{~S}$ on ALDH expression and activity, and the roles of $\mathrm{H}_{2} \mathrm{~S}$ 
in CSC. Therefore, combination of DSF and $\mathrm{H}_{2} \mathrm{~S}$ would be more effective in combating resistant and recurrent cancer.

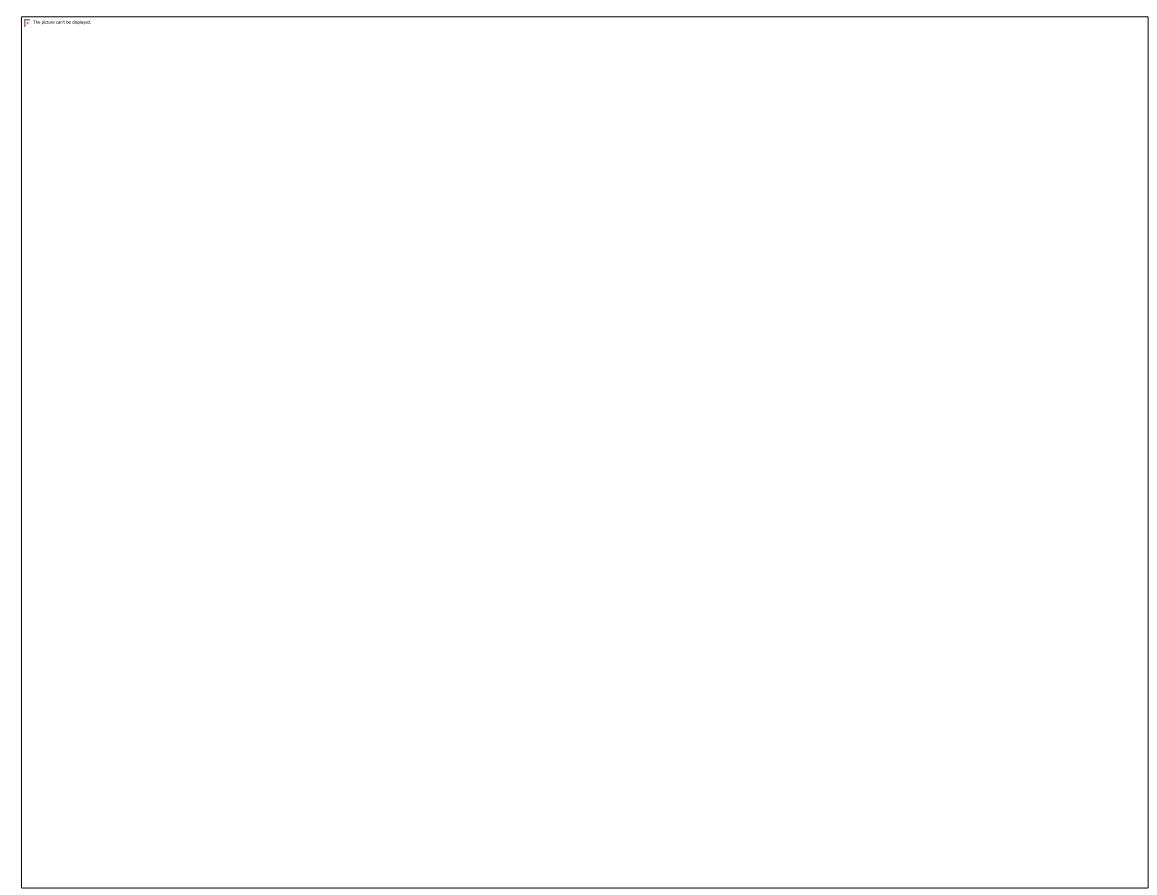

Figure 12 The proposed pathways for DSF-CSE-H2S interactions and their combinational effects on CSC functions.

\section{Limitation and future study}

The purpose of this work was to examine $\mathrm{H}_{2} \mathrm{~S}$ as a potential inhibitor of ALDH, and to assess the impacts of such a role on cancer stem cell function. While the inhibitory effects of $\mathrm{H}_{2} \mathrm{~S}$ on ALDH were validated both in vitro with human liver cell line and ex vivo with mouse liver tissue, the mechanism of inhibition remains unclear. $S$-sulfhydration remains the most likely cause, and work using biotin switch assay and LC-MS analysis could confirm both the site of inhibition and the structure of the inhibitory adduct. With their similar abilities to inhibit ALDH activity, the overlap in biochemical targets between $\mathrm{H}_{2} \mathrm{~S}$ and DSF should be examined to determine novel targets for both compounds. 
While DSF-induced $\mathrm{H}_{2} \mathrm{~S}$ generation is CSE dependent, the nature of this interaction is unknown. DSF may act to promote CSE activity, or may be a novel CSE metabolite, and the work to determine where and how DSF and CSE react should be conducted. Additionally, the use of DSF as a $\mathrm{H}_{2} \mathrm{~S}$ donor should be determined in vivo, to verify whether DSF could function in a clinical capacity.

The limited evidence of $\mathrm{H}_{2} \mathrm{~S}$ on $\mathrm{CSC}$ function should be expanded upon. While the decreased cell adhesion in the CSC model after $\mathrm{H}_{2} \mathrm{~S}$ treatment certainly indicates a reduction in stemness, additional characteristics such as MDR, cell migration, and CSC marker expression may provide greater support for $\mathrm{H}_{2} \mathrm{~S}$ as a CSC treatment. Further, while inhibition of ALDH activity certainly reduces resistance to chemotherapy, the decreased stemness seen due to $\mathrm{H}_{2} \mathrm{~S}$ is likely the cause of Gli2 destabilization. Efforts should be made to determine how $\mathrm{H}_{2} \mathrm{~S}$ regulates ALDH expression, and to identify any associated transcription factors. $\mathrm{H}_{2} \mathrm{~S}$ donors with greater bioavailability than NaHS must also be used in vivo to determine their validity as clinical treatment for CSC. 


\section{References}

1. Alfarouk KO, Stock C-M, Taylor S, et al. Resistance to cancer chemotherapy: failure in drug response from ADME to P-gp. Cancer Cell Int. 2015, 15:71.

2. Reya T, Morrison SJ, Clarke MF, Weissman IL. Stem cells, cancer, and cancer stem cells. Nature. 2001, 414(6859):105-111.

3. Lapidot T, Sirard C, Vormoor J, et al. A cell initiating human acute myeloid leukaemia after transplantation into SCID mice. Nature. 1994, 367(6464):645-648.

4. Eramo A, Lotti F, Sette G, et al. Identification and expansion of the tumorigenic lung cancer stem cell population. Cell Death Differ. 2008, 15(3):504-514.

5. Sylvester KG, Longaker MT. Stem cells: review and update. Arch of Surg. 2004, 139(1):9399.

6. Yoganandarajah V, Patel J, van Schaijik B, et al. Identification of cancer stem cell subpopulations in head and neck metastatic malignant melanoma. Cells. 2020, 9(2):324.

7. Singh SK, Clarke ID, Terasaki M, et al. Identification of a cancer stem cell in human brain tumors. Cancer Res. 2003, 63(18):5821-5828.

8. Zheng H, Pomyen Y, Hernandez MO, et al. Single-cell analysis reveals cancer stem cell heterogeneity in hepatocellular carcinoma. Hepatology. 2018, 68(1):127-140.

9. Al-Hajj M, Wicha MS, Benito-Hernandez A, Morrison SJ, Clarke MF. Prospective identification of tumorigenic breast cancer cells. Proc Natl Acad Sci USA. 2003, 100(7):3983-3988. 
10. Clarke MF, Hass AT. Cancer stem cells. Reviews in Cell Biology and Molecular Medicine. American Cancer Society; 2006.

11. Karsten U, Goletz S. What makes cancer stem cell markers different? Springer plus. 2013, 2(1):301.

12. Wulfkuhle JD, Liotta LA, Petricoin EF. Proteomic applications for the early detection of cancer. Nat Rev Cancer. 2003, 3(4):267-275.

13. Ali HR, Dawson S-J, Blows FM, Provenzano E, Pharoah PD, Caldas C. Cancer stem cell markers in breast cancer: pathological, clinical and prognostic significance. Breast Cancer Res. 2011, 13(6):R118.

14. Agliano A, Calvo A, Box C. The challenge of targeting cancer stem cells to halt metastasis. Sem Cancer Biol. 2017, 44:25-42.

15. Attia YM, El-Kersh DM, Ammar RA, et al. Inhibition of aldehyde dehydrogenase-1 and pglycoprotein-mediated multidrug resistance by curcumin and vitamin D3 increases sensitivity to paclitaxel in breast cancer. Chemi-Biol Interact. 2020, 315:108865.

16. Toledo-Guzmán ME, Hernández MI, Gómez-Gallegos ÁA, Ortiz-Sánchez E. ALDH as a stem cell marker in solid tumors. Curr Stem Cell Res Ther. 2019, 14(5):375-388.

17. Croker AK, Allan AL. Inhibition of aldehyde dehydrogenase (ALDH) activity reduces chemotherapy and radiation resistance of stem-like $\mathrm{ALDH}{ }^{\mathrm{hi}} \mathrm{CD} 44^{+}$human breast cancer cells. Breast Cancer Res Treat. 2012, 133(1):75-87. 
18. Dinavahi SS, Bazewicz CG, Gowda R, Robertson GP. Aldehyde dehydrogenase inhibitors for cancer therapeutics. Trends Pharmacol Sci. 2019, 40(10):774-789.

19. Raha D, Wilson TR, Peng J, et al. The cancer stem cell marker aldehyde dehydrogenase is required to maintain a drug-tolerant tumor cell subpopulation. Cancer Res. 2014, 74(13):3579-3590.

20. Jiménez R, Pequerul R, Amor A, et al. Inhibitors of aldehyde dehydrogenases of the $1 \mathrm{~A}$ subfamily as putative anticancer agents: Kinetic characterization and effect on human cancer cells. Chem Biol Interact. 2019, 306:123-130.

21. Zhao J. Cancer stem cells and chemoresistance: The smartest survives the raid. PharmacolTher. 2016, 160:145-158.

22. Huang C-P, Tsai M-F, Chang T-H, et al. ALDH-positive lung cancer stem cells confer resistance to epidermal growth factor receptor tyrosine kinase inhibitors. Cancer Letters. $2012,328$.

23. Yan Z, Xu L, Zhang J, Lu Q, Luo S, Xu L. Aldehyde dehydrogenase 1A1 stabilizes transcription factor Gli2 and enhances the activity of Hedgehog signaling in hepatocellular cancer. Biochem BiophysRes Com. 2016, 471(4):466-473.

24. Kim MP, Fleming JB, Wang H, et al. ALDH activity selectively defines an enhanced tumorinitiating cell population relative to CD133 expression in human pancreatic adenocarcinoma. PLOS ONE. 2011, 6(6):e20636. 
25. Crabb DW, Matsumoto M, Chang D, You M. Overview of the role of alcohol dehydrogenase and aldehyde dehydrogenase and their variants in the genesis of alcoholrelated pathology. Proc Nutri Soc. 2004, 63(1):49-63.

26. Alnouti $\mathrm{Y}$, Klaassen $\mathrm{CD}$. Tissue distribution, ontogeny, and regulation of aldehyde dehydrogenase (aldh) enzymes mrna by prototypical microsomal enzyme inducers in mice. Toxicol Sci. 2008, 101(1):51-64.

27. Yoon M, Madden MC, Barton HA. Developmental expression of aldehyde dehydrogenase in rat: a comparison of liver and lung development. Toxicol Sci. 2006, 89(2):386-398.

28. Eneanya DI, Bianchine JR, Duran DO, Andresen BD. The actions and metabolic fate of disulfiram. Annu Rev Pharmacol Toxicol. 1981, 21(1):575-596.

29. Fuller RK, Branchey L, Brightwell DR, et al. Disulfiram treatment of alcoholism: a veterans administration cooperative study. JAMA. 1986, 256(11):1449-1455.

30. Hald J, Jacobsen E, Larsen V. The sensitizing effect of tetraethylthiuramdisulphide (antabuse) to ethylalcohol. Acta Pharmacol Toxicol. 1948, 4(3-4):285-296.

31. Petersen EN. The pharmacology and toxicology of disulfiram and its metabolites. Acta Psychiatr Scand. 1992, 86(S369):7-13.

32. Brewer C, Streel E, Skinner M. Supervised disulfiram's superior effectiveness in alcoholism treatment: ethical, methodological, and psychological aspects. Alcohol Alcohol. 2017, 52(2):213-219. 
33. Schmidtova S, Kalavska K, Gercakova K, et al. Disulfiram overcomes cisplatin resistance in human embryonal carcinoma cells. Cancers. 2019, 11(9):1224.

34. Chen D, Cui QC, Yang H, Dou QP. Disulfiram, a clinically used anti-alcoholism drug and copper-binding agent, induces apoptotic cell death in breast cancer cultures and xenografts via inhibition of the proteasome activity. Cancer Res. 2006, 66(21):10425-10433.

35. Zhang X, Hu P, Ding S-Y, et al. Induction of autophagy-dependent apoptosis in cancer cells through activation of ER stress: an uncovered anti-cancer mechanism by anti-alcoholism drug disulfiram. Am J Cancer Res. 2019, 9(6):1266-1281.

36. Park YM, Go YY, Shin SH, Cho J-G, Woo J-S, Song J-J. Anti-cancer effects of disulfiram in head and neck squamous cell carcinoma via autophagic cell death. PLOS ONE. 2018, 13(9):e0203069.

37. Skrott Z, Majera D, Gursky J, et al. Disulfiram's anti-cancer activity reflects targeting NPL4, not inhibition of aldehyde dehydrogenase. Oncogene. 2019, 38(40):6711-6722.

38. MacDonagh L, Gallagher MF, Ffrench B, et al. Targeting the cancer stem cell marker, aldehyde dehydrogenase 1, to circumvent cisplatin resistance in NSCLC. Oncotarget. 2017, 8(42):72544-72563.

39. Wang N, Wang L-H, Li Y, et al. Targeting ALDH2 with disulfiram/copper reverses the resistance of cancer cells to microtubule inhibitors. Exp Cell Res. 2017, 362.

40. Nwani NG, Condello S, Wang Y, et al. A Novel ALDH1A1 Inhibitor targets cells with stem cell characteristics in ovarian cancer. Cancers. 2019, 11(4):502. 
41. Islam SS, Al-Sharif I, Sultan A, Al-Mazrou A, Remmal A, Aboussekhra A. Eugenol potentiates cisplatin anti-cancer activity through inhibition of ALDH-positive breast cancer stem cells and the NF-кB signaling pathway. Mol Carcino. 2018, 57(3):333-346.

42. Alharbi FF, el-Guebaly N. The relative safety of disulfiram. Addict Disord Treat 2013, 12(3):140-147.

43. Berlin RG. Disulfiram hepatotoxicity: a consideration of its mechanism and clinical spectrum. Alcohol Alcohol. 1989, 24(3):241-246.

44. Lipsky JJ, Shen ML, Naylor S. In vivo inhibition of aldehyde dehydrogenase by disulfiram. Chemi-Biol Interact. 2001, 130-132:93-102.

45. Kitson TM. Mechanism of inactivation of sheep liver cytoplasmic aldehyde dehydrogenase by disulfiram. Biochem J. 1983, 213(2):551-554.

46. Johansson B, Stankiewicz Z. Bis-(diethyldithiocarbamato) copper complex: a new metabolite of disulfiram? Biochem Pharmacol. 1985, 34(16):2989-2991.

47. Johansson B. A review of the pharmacokinetics and pharmacodynamics of disulfiram and its metabolites. Acta Psychiatr Scand. 1992, 86(S369):15-26.

48. Lipsky JJ, Shen ML, Naylor S. Overview — In vitro inhibition of aldehyde dehydrogenase by disulfiram and metabolites. Chem-Biol Interact. 2001, 130-132:81-91.

49. Li H, Wang J, Wu C, Wang L, Chen Z-S, Cui W. The combination of disulfiram and copper for cancer treatment. Drug Discov Today. 2020, 25(6):1099-1108. 
50. Liu X, Wang L, Cui W, et al. Targeting ALDH1A1 by disulfiram/copper complex inhibits non-small cell lung cancer recurrence driven by ALDH-positive cancer stem cells. Oncotarget. 2016, 7(36):58516-58530.

51. Cen D, Brayton D, Shahandeh B, Meyskens Frank L, Farmer PJ. Disulfiram facilitates intracellular cu uptake and induces apoptosis in human melanoma cells. J Med Chem. 2004, 47(27):6914-6920.

52. Allensworth JL, Evans MK, Bertucci F, et al. Disulfiram (DSF) acts as a copper ionophore to induce copper-dependent oxidative stress and mediate anti-tumor efficacy in inflammatory breast cancer. Mol Onco. 2015, 9(6):1155-1168.

53. Wang R. Gasotransmitters: growing pains and joys. Trends Biochem Sci. 2014, 39(5):227232.

54. Wang R. Physiological implications of hydrogen sulfide: a whiff exploration that blossomed. Physiol Rev. 2012, 92(2):791-896.

55. Wang R. The gasotransmitter role of hydrogen sulfide. Antioxid Redox Signal. 2003, 5(4):493-501.

56. Wang R. Two's company, three's a crowd: can $\mathrm{H}_{2} \mathrm{~S}$ be the third endogenous gaseous transmitter? The FASEB Journal. 2002, 16(13):1792-1798.

57. Cooper CE, Brown GC. The inhibition of mitochondrial cytochrome oxidase by the gases carbon monoxide, nitric oxide, hydrogen cyanide and hydrogen sulfide: chemical mechanism and physiological significance. Bioenerg Biomemb. 2008, 40(5):533. 
58. Abe K, Kimura H. The possible role of hydrogen sulfide as an endogenous neuromodulator. J Neurosci. 1996, 16(3):1066-1071.

59. Kamoun P. Endogenous production of hydrogen sulfide in mammals. Amino acids. 2004, 26(3):243-254.

60. Kabil O, Vitvitsky $\mathrm{V}$, Xie $\mathrm{P}$, Banerjee $\mathrm{R}$. The quantitative significance of the transsulfuration enzymes for $\mathrm{H}_{2} \mathrm{~S}$ production in murine tissues. AntioxRedox Signal. 2011, 15(2):363-372.

61. Zhao W, Ndisang JF, Wang R. Modulation of endogenous production of $\mathrm{H}_{2} \mathrm{~S}$ in rat tissues. Can J Physiol Pharmacol. 2003, 81(9):848-853.

62. Mustafa AK, Gadalla MM, Sen N, et al. $\mathrm{H}_{2} \mathrm{~S}$ signals through protein $S$-sulfhydration. $S c i$ Signal. 2009, 2(96):ra72.

63. Read E, Zhu J, Yang G. Disrupted $\mathrm{H}_{2} \mathrm{~S}$ signaling by cigarette smoking and alcohol drinking: evidence from cellular, animal, and clinical studies. Antioxidants. 2021, 10(1):49.

64. Yang $\mathrm{G}, \mathrm{Wu} \mathrm{L}$, Jiang $\mathrm{B}$, et al. $\mathrm{H}_{2} \mathrm{~S}$ as a physiologic vasorelaxant: hypertension in mice with deletion of cystathionine $\gamma$-lyase. Science. 2008, 322(5901):587-590.

65. Ali A, Zhang Y, Fu M, et al. Cystathionine gamma-lyase/ $\mathrm{H}_{2} \mathrm{~S}$ system suppresses hepatic acetyl-CoA accumulation and nonalcoholic fatty liver disease in mice. Life Sci. 2020, 252:117661.

66. Kimura H. Signaling of hydrogen sulfide and polysulfides. Antioxi Redox Signal. 2014, 2(5):347-349. 
67. Mani Sarathi, Li Hongzhu, Untereiner Ashley, et al. Decreased endogenous production of hydrogen sulfide accelerates atherosclerosis. Circulation. 2013, 127(25):2523-2534.

68. Motohashi H, Yamamoto M. Nrf2-Keap1 defines a physiologically important stress response mechanism. Trends Mol Med.. 2004, 10(11):549-557.

69. Itoh K, Chiba T, Takahashi S, et al. An Nrf2/small Maf heterodimer mediates the induction of phase II detoxifying enzyme genes through antioxidant response elements. Biochem Biophys Res Commun. 1997, 236(2):313-322.

70. Kimura Y, Goto Y-I, Kimura H. Hydrogen sulfide increases glutathione production and suppresses oxidative stress in mitochondria. Antioxi Redox Signal. 2009, 12(1):1-13.

71. Paul BD, Snyder $\mathrm{SH} . \mathrm{H}_{2} \mathrm{~S}$ : A novel gasotransmitter that signals by sulfhydration. Trends Biochem Sci. 2015, 40(11):687-700.

72. Hourihan JM, Kenna JG, Hayes JD. The Gasotransmitter hydrogen sulfide induces nrf2target genes by inactivating the Keap1 ubiquitin ligase substrate adaptor through formation of a disulfide bond between Cys-226 and Cys-613. Antioxi Redox Signal. 2012, 19(5):465481.

73. Koike S, Ogasawara Y, Shibuya N, Kimura H, Ishii K. Polysulfide exerts a protective effect against cytotoxicity caused by $t$-buthylhydroperoxide through $\mathrm{Nrf2}$ signaling in neuroblastoma cells. FEBS Letters. 2013, 587(21):3548-3555.

74. Kimura H. Physiological role of hydrogen sulfide and polysulfide in the central nervous system. Neurochem Int. 2013, 63(5):492-497. 
75. Módis K, Ju Y, Ahmad A, et al. S-Sulfhydration of ATP synthase by hydrogen sulfide stimulates mitochondrial bioenergetics. Pharmacol Res. 2016, 113:116-124.

76. Zhang Z, Fang X, Yang X, et al. Hydrogen sulfide donor NaHS alters antibody structure and function via sulfhydration. Int Immunopharmacol. 2019, 73:491-501.

77. Sun H-J, Xiong S-P, Cao X, et al. Polysulfide-mediated sulfhydration of SIRT1 prevents diabetic nephropathy by suppressing phosphorylation and acetylation of p65 NF-kB and STAT3. Redox Biol. 2021, 38:101813.

78. Reis AKCA, Stern A, Monteiro HP. S-nitrosothiols and $\mathrm{H}_{2} \mathrm{~S}$ donors: Potential chemotherapeutic agents in cancer. Redox Biol. 2019, 27:101190.

79. Lee ZW, Zhou J, Chen C-S, et al. The slow-releasing hydrogen sulfide donor, GYY4137, exhibits novel anti-cancer effects in vitro and in vivo. PLOS ONE. 2011, 6(6):e21077.

80. Bigagli E, Luceri C, De Angioletti $\mathrm{M}$, et al. New NO- and $\mathrm{H}_{2} \mathrm{~S}$-releasing doxorubicins as targeted therapy against chemoresistance in castration-resistant prostate cancer: in vitro and in vivo evaluations. Invest New Drugs. 2018, 36(6):985-998.

81. Stokes E, Shuang T, Zhang $\mathrm{Y}$, et al. Efflux inhibition by $\mathrm{H}_{2} \mathrm{~S}$ confers sensitivity to doxorubicin-induced cell death in liver cancer cells. Life Sci. 2018, 213:116-125.

82. Loiselle JJ, Yang G, Wu L. Hydrogen sulfide and hepatic lipid metabolism - a critical pairing for liver health. Br J Pharmacol. 2020, 177:757-768. 
83. Iciek M, Górny M, Bilska-Wilkosz A, Kowalczyk-Pachel D. Is aldehyde dehydrogenase inhibited by sulfur compounds? In vitro and in vivo studies. Acta Biochim Pol. 2018, 65(1):125-132.

84. Lacoste B, Raymond V-A, Cassim S, Lapierre P, Bilodeau M. Highly tumorigenic hepatocellular carcinoma cell line with cancer stem cell-like properties. PLoS One. 2017, 12(2).

85. Hine C, Mitchell JR. Endpoint or kinetic measurement of hydrogen sulfide production capacity in tissue extracts. Bio Protoc. 2017, 7(13).

86. Zhang Y, Ali A, Jin Z, Pei Y, Yang G. Induction of cystathionine gamma-lyase expression and metallothionein-1 $S$-sulfhydration alleviate cadmium-induced cell death in myoblast cells. Ecotoxicol Environ Saf. 2019, 179:222-231.

87. Liu J-J, Lin D-J, Liu P-Q, Huang M, Li X-D, Huang R-W. Induction of apoptosis and inhibition of cell adhesive and invasive effects by tanshinone IIA in acute promyelocytic leukemia cells in vitro. J Biomed Sci. 2006, 13:813-823.

88. Kreso A, Dick JE. Evolution of the cancer stem cell model. Cell Stem Cell. 2014, 14(3):275291.

89. Yang L, Shi P, Zhao G, et al. Targeting cancer stem cell pathways for cancer therapy. Signal Transduct Target Thera. 2020, 5(1):1-35. 
90. Bourque $\mathrm{C}$, Zhang $\mathrm{Y}, \mathrm{Fu} \mathrm{M}$, et al. $\mathrm{H}_{2} \mathrm{~S}$ protects lipopolysaccharide-induced inflammation by blocking NFאB transactivation in endothelial cells. Toxicol Appl Pharmacol. 2018, 338:20-29.

91. Madan A, Williams TD, Faiman MD. Glutathione- and glutathione-S-transferase-dependent oxidative desulfuration of the thione xenobiotic diethyldithiocarbamate methyl ester. Mol Pharmacol. 1994, 46(6):1217-1225.

92. Deneke SM, Harford PH, Lee KY, Deneke CF, Wright SE, Jenkinson SG. Induction of cystine transport and other stress proteins by disulfiram: effects on glutathione levels in cultured cells. Am J Respir Cell Mol Biol. 1997;17:227-234.

93. Shi H, Sun Y, Zhang Z, Liu R, Liu H, Cheng Z. Copper(II)-disulfiram loaded melanin-dots for cancer theranostics. Nanomedicine. 2020, 32(102340).

94. Zuhra K, Panagaki T, Randi EB, et al. Mechanism of cystathionine- $\beta$-synthase inhibition by disulfiram: The role of bis(N,N-diethyldithiocarbamate)-copper(II). Biochem Pharmacol. 2020, 182:114267.

95. Lu S, Gao Y, Huang X, Wang X. GYY4137, a hydrogen sulfide $\left(\mathrm{H}_{2} \mathrm{~S}\right)$ donor, shows potent anti-hepatocellular carcinoma activity through blocking the STAT3 pathway. Int J Onco. 2014, 44(4):1259-1267.

96. Wang W, Liu H, Lu Y, et al. Controlled-releasing hydrogen sulfide donor based on dualmodal iron oxide nanoparticles protects myocardial tissue from ischemia-reperfusion injury. Int J Nanomedicine. 2019, 14:875-888. 
97. Liu S-Y, Zheng P-S. High aldehyde dehydrogenase activity identifies cancer stem cells in human cervical cancer. Oncotarget. 2013, 4(12):2462-2475.

98. Ma S, Chan KW, Lee TK-W, et al. Aldehyde dehydrogenase discriminates the CD133 liver cancer stem cell populations. Mol Cancer Res. 2008, 6(7):1146-1153.

99. Upadhyaya B, Liu Y, Dey M. Phenethyl Isothiocyanate Exposure Promotes Oxidative Stress and Suppresses Sp1 Transcription Factor in Cancer Stem Cells. Int J Mol Sci. 2019, 20(5):1027.

100. Vishnubalaji R, Manikandan M, Fahad M, et al. Molecular profiling of ALDH1 ${ }^{+}$colorectal cancer stem cells reveals preferential activation of MAPK, FAK, and oxidative stress prosurvival signalling pathways. Oncotarget. 2018, 9(17):13551-13564.

101. Cassim S, Raymond V-A, Lacoste B, Lapierre P, Bilodeau M. Metabolite profiling identifies a signature of tumorigenicity in hepatocellular carcinoma. Oncotarget. 2018, 9(42):26868-26883.

102. Lancien M, Gueno L, Salle S, et al. Cystathionine-gamma-lyase overexpression in T cells enhances antitumor effect independently of cysteine autonomy. Cancer Sci. 2021.

103. Lin Z, Huang W, He Q, et al. FOXC1 promotes HCC proliferation and metastasis by Upregulating DNMT3B to induce DNA hypermethylation of CTH promoter. $J$ Exp ClinCancer Res. 2021, 40(1):50. 
104. Lun X, Wells JC, Grinshtein N, et al. Disulfiram when combined with copper enhances the therapeutic effects of temozolomide for the treatment of glioblastoma.Clin Cancer Res. 2016, 22(15):3860-3875.

105. Wang W, McLeod H, Cassidy J. Disulfiram-mediated inhibition of NF-kappaB activity enhances cytotoxicity of 5-fluorouracil in human colorectal cancer cell lines. Int J Cancer. 2003, 104:504-511.

106. Yang G, Wu L, Bryan S, Khaper N, Mani S, Wang R. Cystathionine gamma-lyase deficiency and overproliferation of smooth muscle cells. Cardiovasc Res. 2010, 86(3):487495.

107. Silver DJ, Roversi GA, Bithi N, et al. Cancer stem cell enrichment and metabolic substrate adaptability are driven by hydrogen sulfide suppression in glioblastoma. bioRxiv. Published online March 10, 2020:2020.03.08.982116.

108. Yang G. $\mathrm{H}_{2} \mathrm{~S}$ as a potential defense against COVID-19? Am J Physiol-Cell Physiol. 2020, 319(2):C244-C249.

109. Mani S, Cao W, Wu L, Wang R. Hydrogen sulfide and the liver. Nitric Oxide. 2014, 41:6271.

110. Zhao K, Li H, Li S, Yang G. Regulation of cystathionine gamma-lyase/ $\mathrm{H}_{2} \mathrm{~S}$ system and its pathological implication. Front Biosci (Landmark Ed). 2014, 19:1355-1369. 
111. Zhen Y, Wu Q, Ding Y, et al. Exogenous hydrogen sulfide promotes hepatocellular carcinoma cell growth by activating the STAT3-COX-2 signaling pathway. Oncol Lett. 2018, 15(5):6562-6570.

112. Ma Z, Bi Q, Wang Y. Hydrogen sulfide accelerates cell cycle progression in oral squamous cell carcinoma cell lines. Oral Dis. 2015, 21(2):156-162.

113. Kashfi $\mathrm{K}$. The dichotomous role of $\mathrm{H}_{2} \mathrm{~S}$ in cancer cell biology? Déjà vu all over again. Biochem Pharmacol. 2018, 149:205-223.

114. Wu D, Si W, Wang M, Lv S, Ji A, Li Y. Hydrogen sulfide in cancer: Friend or foe? Nitric Oxide. 2015, 50:38-45.

115. Spillier Q, Vertommen D, Ravez S, et al. Anti-alcohol abuse drug disulfiram inhibits human PHGDH via disruption of its active tetrameric form through a specific cysteine oxidation. Sci Rep. 2019, 9(1):1-9. 